Давыдов А.П.

\title{
Поэзия Корана выше Корана (А. С. Пушкин. Цикл стихотворений «Подражания Корану» 1 и комментарий к нему Ф. М. Достоевского²)
}

Аннотациия: В статье опровергается оценка Ф. М. Достоевским пушкинского стихотворного цикла «Подражания Корану», высказанная им в «Пушкинской речи» 8 июня 1880 г., где писатель интерпретирует этот цикл как религиозно-народнический. Достоевский интерпретировал в ней Пушкина -- певца принципа личности как идеолога соборно-авторитарных цеенностей религиозного народа, империи, церкви, почвы, делал его как бы идейным союзником в своей идеологической работе. С этой точки зрения его Пушкинская речь была объективно антипушкинской речъю, искажающей ценностный мир поэта. В статъе доказывается, что Пушкин на материале текстов Корана преследовал чисто творческие цели, создавая русскую поэзию. Применен сравнительный анализ логики мышления Мохаммеда и Пушкина, а также приведены неадекватные оценки Достоевского. Если Мохаммед оперировал смыслами Бога и народа, то Пушкин формировал поэтические смыслы в «сфере между» этими абсолютами. Впервые в достоевсковедении осуществляется социокультурный анализ несостоятельности точки зрения Достоевского на пушкинский стихотворный цикл «Подражания Корану», опираясь на сравнительный анализ ценностей личности. которыми оперировал Пушкин, и народно-религиозных ценностей Корана. Тем самым вывод об искажении Достоевским смысла «Подражаний Корану» переходит из статуса декларируемого в статус доказанного. Это позволяет продвинуться вперед в понимания «Пушкинской речи» как объективно антипушкинской.

Review: The author of the present research article disproves of Fedyor Dostoevsky's appraisal of Pushkin's series of poems 'Imitations of Quran' shared by Dostoevsky shared during his 'speech devoted to Pushkin' on June 8, 1880 when the writer interpreted the aforesaid series of poems as being written according to Russian populist religious traditions. Dostoevsky spoke of Pushkin as an ideologist of the empire, church, religious nation and Russian roots. From this point of view, his speech devoted to Pushkin was an 'anti-Pushkin' speech that actually disguised Pushkin's system of values. The author of the present article proves that referring to Quran Pushkin pursued only creative goals. The only Pushkin's goal was to create Russian poetry. Davydov uses the comparative analysis for studying Muhammad's and Pushkin's logics of reasoning and gives examples of Dostoevsky's inadequate comments or appraisals. Muhammad used the concepts of 'God' and 'people' while Pushkin created poetic meanings in the sphere 'between' these two absolutes. For the first time in studies of Dostoevsky the researcher proves the failure of Dostoevsky's point of view on Pushkin's series of poems 'Imitations of Quran' based on the comparative analysis of personal values used by Pushkin and religious values of Quran. Therefore the conclusion about Dostoevsky's misinterpretation of the meaning of 'Imitations of Quran' can be considered to have been proved. This allows to progress in our understanding of the speech devoted to Pushkin as an objectively anti-Pushkin speech.

Ключевъе слова: Пушкин, Достоевский, Коран, стихотворение Подражания Корану, комментарий, поэзия, искусство, Аллах, Бог, Цель поэзии поэзия.

Keywords: Pushkin, Dostoevsky, Quran, poem, Imitations of Quran, comments, poetry, art, Allah, God, the purpose of poetry, poetry.

\footnotetext{
${ }^{1}$ Пушкия А. С. Подражания Корану. Посвящено П. А. Осиповой.// Пуикин А. С. Полное собрание сочинений в десяти томах. М. -- Л. Издательство АН СССР. Т. 2. С. 204 -- 211. «Подражания Корану» написаны в ноябре 1824 г. Впервые опубликованы в 1826 г. В них Пушкин воспользовался переводом Корана с французского на русский М. И. Веревкина изд. 1790 г. Далее по тексту ссылки на произведения Пушкина приводятся как: Пушкин. Номер тома и номер страницы.

${ }^{2}$ Достоевский Ф. М. «Дневник писателя» на 1880 год. Пушкин (очерк). Произнесено 8 июня в заседании Общества любителей российской словесности.// Достоевский Ф. М. Полное собрание сочинений в тридцати томах. Л., «Наука». 1980. Т. 26. С. 136-149. Далее по тексту ссылки на произведения Достоевского приводятся как: Достоевский. Номер тома и номер страницы.
} 


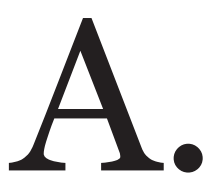

С. Пушкин - о Коране: «Нечестивые, пишет Магомет (глава $\mathrm{Ha}$ грады), думают, что Коран есть собрание новой лжи и старых басен». Мнение сих нечестивых, конечно, справедливо; но, несмотря на сие, многие нравственные истины изложены в Коране сильным и поэтическим образом». ${ }^{3}$

$\Phi$. М. Достоевский - о пушкинских «Подражаниях Корану»: ««Вот рядом с этим религиозным мистицизмом религиозные же строфы из Корана или «Подражания Корану»: разве тут не мусульманин, разве это не самый дух Корана и меч его, простодушная величавость веры и грозная кровавая сила ее?».4

Я расположил рядом эти два высказывания Пушкина и Достоевского, чтобы показать автор «Подражаний» и их комментатор подходили к своей работе, решая разные идейные задачи: Пушкин писал поэзию, Достоевский утверждал себя как идеолога. Поэта Пушкина привлекла в Коране поэзия, и, перерабатывая эту поэзию, он пишет стихотворный цикл «Подражание Корану». Идеолога Достоевского интересует в Коране его религиозно-народническое содержание, и он приписывает пушкинскому циклу то, чего в нем нет - религиозное содержание арабской народной культуры VI века н. э., то есть эпохи создания Корана. Достоевский искажал Пушкина.

Доказательству этого вывода посвящена данная статья.

\section{1. Коран и поэзия Пушкина}

В чем смысл Корана? Эта священная для мусульман книга определяет религиозный механизм веры ислама: проповеди, обрядовые и юридические установления, заклинания, молитвы, притчи, произнесенные пророком Мухаммедом, но вложенные в уста Аллаха.

В чем смысл пушкинских «Подражаний Корану» и его восточных мотивов? Пушкин берет коранические образы, темы, художественные приемы и, разрабатывая их, создает оригинальные стихи.

Дух Корана - дидактический, религиозный, утопающий в самообожании, несущий устрашение неверным и месть за измену вере. Он нацели-

${ }_{3}$ Пушкин А. С. Подражания Корану. Примечания. // Пушкин. Т. 2. С. 210.

4 Достоевский Ф. М. «Дневник писателя» на 1880 год. Пушкин (очерк). Произнесено 8 июня в заседании Общества любителей российской словесности.// Достоевский Ф. М. Т. 26. С. 146. вает человека на беззаветную веру в Абсолюта и погружает человека в арабские народные правила общежития и обряды. В «Подражаниях» Пушкин равнодушен и к исламу, и к Аллаху, и к Пророку, и к Корану, и к арабскому народу как таковым. Коран для него - лишь источник поэзии.

Почему источник поэзии? Прежде всего, потому что многие суры Корана написаны в стихах. Исследователь Корана Рустам Алиев: «Из 114 сур (глав) Корана 48 носят отчетливо выраженный поэтический характер. Здесь слиты в единое целое поэтическая речь, рифмованная проза, аллитерация, звуковая инструментовка, ораторские приемы, торжественность, пафос...».5 На поэзию Корана обращали внимание и противники Мохаммеда, «неверные». Они, не доверяя его поэзии, требовали, чтобы он представил им знамение Аллаха: «Пучки снов! Да, измыслил он его облыжно! Да, он поэт! Пусть же он придет к нам со знамением, как посылались первые!». ${ }^{6}$ Два поэта - Пушкин и Мохаммед - как бы установили мост друг с другом, как бы говорят друг с другом, и местом встречи явились поэтические строфы Священной книги мусульман.

Пушкин старался читать всю доступную ему зарубежную литературу - и греков, и римлян, и итальянцев, и французов, и англичан, и немцев, и поляков. Читая, он учился писать. У всех. Вспомним: сюжеты «Каменного гостя», «Пира во время чумы», «Скупого рыцаря», «Странника» и других произведений - их Пушкин взял из западной литературы. Как источник сюжетов и образов, как произведение Мохаммеда Коран для Пушкина ничем не отличался от произведений поэтов Европы. «Слог восточный был для меня образцом, сколько возможно нам, благоразумным, холодным европейцам», - писал Пушкин П. А. Вяземскому весной 1825 г.

Поэт пишет «Подражания Корану» (1824), находясь в селе Михайловском в ссылке (1824 - 1826). Сравнивает себя, уединенно читающего Коран, с пророком Мохаммедом, который, согласно преданию, долго молился Аллаху в уединении в пещере горы Хира, где

${ }_{5}^{5}$ Алиев Р. Послесловие. // Коран. С. 730.

${ }^{6}$ Аят 5, сура 21 «Пророки». // Коран. Перевод и комментарии И. Ю. Крачковского. М., Главная редакция восточной литературы издательства «Наука». Язычи. 1990. С. 266. Далее ссылки на текст Корана приводятся как: Коран. Номер страницы.

7 Пушкин А. С. -- Вяземскому П. А. Конец марта -начало апреля 1825 г. Из Михайловского в Москву. // Пушикн. Т. 10. С. 135. 
ночью 27 числа месяца рамадана 610 г. явился ему ангел Джибраил (библ. Гавриил) с «Небесной Книгой»- Кораном. Этот сюжет, взятый Пушкиным из суры «Ночь Свершения», поэт положил в основание семи поэтических строчек.

В пещере тайной, в день гоненья,

Читал я сладостный Коран,

Внезапно ангел утешенья,

Влетев, принес мне талисман.

\section{Его таинственная сила}

Слова святые начертила

На нем безвестная рука.

Мусульманские авторы любят цитировать эти строки как признак приверженности Пушкина исламу. Современный пушкинист Кирилл Гордеев пишет, что «с 90-х годов XX века в «мусульманских» республиках России и в некоторых московских изданиях появились публикации, превозносящие «Подражания Корану» Пушкина как свидетельство его обращения в ислам и, соответственно, доказательство преимущества последнего над христианством. Так родился один из мифов времени переиначиваний, лженаучных спекуляций и «свободы слова»» ${ }^{8}$. Омусульманиватели поэта часто ссылаются на пушкинское: «в Коране много мыслей здравых»9. Но здравых мыслей не мало и в «Даодэцзин», и в Библии, и в Торе, и в Талмуде. Если идти этим путем, то всех, кто увидит здравые мысли в Авесте, следует считать зороастрийцем, а кто разглядит что-то разумное в корзинах Трипитаки, последователями Сиддхартхи Гаутамы (Будды). Для этих авторов не имеют значения признания поэта, зачем он изучал Коран. Они слышат только себя.

Но делают из Пушкина приверженца религиозной специфики Корана не только мусульманские авторы. Гордеев сообщает, что П. Анненков - 1874 г., А. Незеленов - 1882 г., Н. Черняев - 1898 г., Д. Овсянико-Куликовский, много писавшие о Пушкине, считали, что поэт

\footnotetext{
${ }^{8}$ Гордеев К. Пушкин А. С. Подражания Корану.// http://www.tatworld.ru/article.shtml?article=240\&secti on $=$ o\&heading $=0$

9 Пушкин А. С. Евгений Онегин. Ранние редакции. Глава 7. Альбом Онегина.// http://www.rvb.ru/pushk in/o1text/o4onegin/o2edit/o853.htm
}

был увлечен религией ислама. ${ }^{10}$ Достоевский в «Пушкинской речи» даже провозгласил: «Вот рядом с этим религиозным мистицизмом религиозные же строфы из Корана или «Подражания Корану»: разве тут не мусульманин, разве это не самый дух Корана и меч его, простодушная величавость веры и грозная кровавая сила еe?». ${ }^{11}$ Философ В. С. Соловьёв считал, что Пушкин любил пророка Мохаммеда, и подчеркивал: «Не каждому дано слышать Священный Коран, как Пушкину, Лермонтову, Тютчеву». ${ }^{12}$ Пушкин действительно «слышал» Коран. Но не так, как казалось его религиозным интерпретаторам. Он «слышал» Коран слухом поэта.

Образы Аллаха, рая, Мекки, Корана, пророка, Востока, гарема, восточной волшебницы, мусульманина присутствуют во многих стихотворениях поэта. Например, в очаровательном «Талисмане»:

Там, где море вечно плещет

На пустынные скалы,

Где луна теплее блещет

В сладкий час вечерней мглы,

Где, в гаремах наслаждаясь,

Дни проводит мусульман

Там волшебница, ласкаясь,

Мне вручила талисман.

И, ласкаясь, говорила:

«Сохрани мой талисман:

В нем таинственная сила!

Он тебе любовью дан.

От недуга, от могилы,

В бурю, в грозный ураган,

Головы твоей, мой милый,

Не спасет мой талисман.

\section{И богатствами Востока}

Он тебя не одарит,

И поклонников пророка

Он тебе не покорит;

И тебя на лоно друга,

От печальных чуждых стран,

В край родной на север с юга

Не умчит мой талисман...

${ }^{10}$ Гордеев К.Пушкин А. С. Подражания Корану.// http://www.tatworld.ru/article.shtml?article=240\&secti on $=$ o\&heading $=0$

${ }^{11}$ Достоевский Ф. М. «Дневник писателя» на 1880 год. Пушкин (очерк). Произнесено 8 июня в заседании Общества любителей российской словесности.// Достоевский. Т. 26. С. 146.

${ }^{12}$ Соловъев В. С. Магомет: Его жизнь и религиозное учение // Библиотека «Вехи». http://islamdag.ru/vseob-islame $/ 7676$ 
Но когда коварны очи

Очаруют вдруг тебя,

Иль уста во мраке ночи

Поцелуют не любя -

Милый друг! От преступленья,

От сердечных новых ран,

От измены, от забвенья

Сохранит мой талисман!». ${ }^{13}$

Какая поэзия! А образы Востока, мусульманина, пророка, гарема - это не Коран, это Восток, осмысленный через образы, краски, музыку, взятые в том числе из Корана. Эти мелодии создают необходимые «истину страстей, правдоподобие чувствований» ${ }^{14}$ и в поэме «Кавказский пленник», и в «Татарской песне» поэмы «Бахчисарайский фонтан». А вот, например, коранический сюжет: как только «слепец»-«неверный»-«нечестивый» подошел к Мохаммеду, чтобы спорить с ним, Аллах вдруг «нахмурился и отвернулся» ${ }^{15}$. Действительно, какой смысл спорить с глупцом? Так родилось пушкинское «Третье подражание» Корану, а в одной из ранних редакций рукописи «Евгения Онегина» появилось четверостишье:

В Коране много мыслей здравых,

Вот, например: «Пред каждым сном

Молись; беги путей лукавых,

Чти Бога и не спорь с глупцом». ${ }^{16}$

Вспомним последнюю строчку из пушкинского «Памятника»: «И не оспоривай глупца» .

А вот строки его «Пророка»:

Он мне грудь рассёк мечом,

И сердце трепетное вынул,

И угль, пылающий огнём,

Во грудь отверстую водвинул.

Образ очищения сердца - из Корана: «Разве не расширили Мы тебе грудь твою и не избавили тебя от ноши твоей?». ${ }^{17}$ И из хадиса о Пророке Мохаммеде: ему ангелы раскрыли

\footnotetext{
${ }^{13}$ Пушкин А. С. Талисман. // Пушкин. Т. 2. С. 35-36.

${ }^{14}$ Пушкин A. C. О народной драме и драме «Марфа Посадница».// Пушкин. Т. 7. С. 211.

${ }^{15}$ Аяты 1-2, сура 80 «Нахмурился». // Коран. С.489.

${ }_{16}$ Пушкин A. C. Евгений Онегин. Ранние редакции. Глава 7. Альбом Онегина.// http://www.rvb.ru/pushki n/o1text/o4onegin/o2edit/o853.htm

${ }_{17}$ Аяты 26(25) - 29(28), сура 20 «Та ха».//Коран. C. 258-259.
}

грудь, вынули и очистили сердце снегом и, вложив его в грудь, удалились. ${ }^{18}$

Но если Пушкину в Коране нужна была, как утверждает сам Пушкин, только поэзия Мохаммеда и ничего более, то откуда Достоевский взял, что в «Подражаниях Корану» - «религиозные строфы», «мусульманин», «вера», «меч» и «дух» Корана? Почему Достоевский ставит знак равенства между Кораном и «Подражаниями Корану»? (Напомню: «Вот рядом с этим религиозным мистицизмом религиозные же строфы из Корана или (курсив мой - А. Д.) «Подражания Корану»: разве тут не мусульманин, разве это не самый дух Корана и меч его, простодушная величавость веры и грозная кровавая сила ее?»). Откуда это уравнивающее Коран и «Подражания Корану» «или»?

\section{2. Заговор Достоевского}

Достоевский, комментируя «Подражания Корану», ставил перед собой идеологическую задачу. 8 июня 1880 г. в своей «Пушкинской речи» он провозгласил тезис о всемирной отзывчивости творчества Пушкина, одновременно подняв знамя всемирной отзывчивости русского народа. На основании всемирной отзывчивости обоих он соединил их в некой народной почве, то есть способности русского человека нести народную правду, единую для всего мира, пытаясь сделать из Пушкина религиозного народника.

Я должен защитить Пушкина от Достоевского. Мне надо показать, что не был Достоевский почитателем Пушкина, он был его принципиальным и тайным противником. Достоевский часто и искренне восхищался Пушкиным как художником, но борьба против идеологии личности, и, следовательно, против Пушкина как ее автора, была основным делом жизни Достоевского. Поздний Гоголь, Достоевский, В. Соловьев, Н. Бердяев, С. Франк вот вехи антипушкинистики, установленные русской религиозной философией ${ }^{19}$. Но ее пиком было творчество Достоевского.

Почему я называю то, что делал Достоевский, заговором? Это была тайная подрывная

\footnotetext{
18 «Ислам и мусульмане в русской литературе XIX века». М., Благотворительный фонд «Путь».//http:// www.islamdag.ru/vse-ob-islame/6048; см. также Фомичев С. А. «Подражания Корану». Генезис, архитектоника и композиция цикла.//

http://feb-web.ru/feb/pushkin/serial/v81/v81-o22-.htm 19 Подробно см. Давыдов А. П. Неполитический либерализм в России. М. Мысль. 2012.
} 
деятельность, маскируемая лояльными словами, восхищением, лестью, преданностью. Достоевский, открыто восхищаясь Пушкиным, но объявив войну принципу личности в русской культуре, не произнося имени Пушкина, уничтожал Пушкина как открывателя этой темы, как автора идеи независимости русского человека от исторически сложившейся в России народной культуры. Но чтобы заговор работал, нужна была умная схема уничтожения Пушкина. Достоевский ее создал. Восхищаясь поэзией Пушкина, он объявил Пушкина автором мыслей, которых тот не имел, провозгласил его носителем идеологии, которой тот не придерживался. Если Гоголь повернул «от Пушкина» открыто, горько сожалея о своем повороте ${ }^{20}$, поворот был для него личной трагедией, то Достоевский, как искусный дипломат, вел двойную игру. Вот почему я называю то, что делал Достоевский, заговором.

Достоевский в этой игре напоминает маньяка, который патологически любит свою жертву. Его жертвой было имя Пушкина. В жонглировании наследием и именем поэта Достоевский был мазохист. Он обожал стихи Пушкина, пушкинский анализ человеческого в человеке, глубину и точность этого анализа. Но втайне, теперь об этом можно определенно сказать, завидовал Пушкину. Чтобы никто не догадался. До смерти. До умопомрачения. Он понимал, что Пушкин - вершина, что поэт стоит на недосягаемом пьедестале. Сбросить его с пьедестала он не мог. Значит - путь один: надо сделать так, чтобы на пьедестале под именем «Пушкин» стоял Достоевский. Надо было сделать из Пушкина почвенника, надо было вычистить из творчества поэта идею личности и ввести в него антиличностную идею религиозного народничества, почвенничества, основоположником которой в России был он - Федор Достоевский. Цель - встать номинально рядом с Пушкиным, но по существу выше Пушкина, потому что опора на личность, на то, чего в России нет, иллюзорна и бессмысленна, а опора на русский народ реальна и делает идеолога народничества бессмертным.

Почему заговор до сих пор не раскрыт и почему мы не видим двойственности слов «Пушкинской речи» и статей Достоевского о Пушкине?

Объективных причин много. Они в народно-религиозной специфике интеллигентской культуры России второй половины XIX века,

${ }^{20}$ См. Давыдов А. П. Душа Гоголя. Опыт социокультурного анализа. М, Новый Хронограф. 2008. когда творил Достоевский. Они в расцвете русской религиозной философии и активном поиске путей спасения России от угрозы гибели в огне Первой мировой войны и революций начала XX вв. Они и в марксистско-ленинской специфике интеллигентской культуры советской России, когда жили читатели-почитатели Достоевского, идеологически ориентированные на прорыв в светлое коммунистическое будущее. А поиск путей в светлое будущее и было главным занятием идеолога Достоевского.

Еще больше субъективных причин. Выступить сегодня против полуторавековой инерции истории и неохватной массы ныне здравствующих академиков?.. Честь сделать эту работу я оставляю другим... Вернее, значимость религиозно-народнической пушкинистики Достоевского рано или поздно умрет сама. Главное сегодня - сохранить для России значение Пушкина как аналитика, впервые в русской культуре на страницах своих произведений поставившего проблему личности. Первый шаг я сделал в своих книгах «Душа Гоголя» и «Неполитический либерализм в России». В них, надеюсь, я раскрыл пушкинское видение смысла личности в русской культуре. Теперь надо сделать второй шаг - раскрыть способ подрыва, подмены Достоевским личностной пушкинской идеологии, механизм, которым он пользовался под благородным флагом прославления всемирной отзывчивости поэта.

\section{3. Пушкин: «Коран - собрание новой лжи и старых басен»}

Этот текст я начал с цитаты из Пушкина о том, что Коран - собрание лжи, ложь, старая, давно с докоранических времен пережевываемая церковниками. Вот высказывание Пушкина в примечании к «Подражаниям Корану». Привожу его в неполном виде:

«Нечестивые, пишет Магомет (глава Награды), думают, что Коран есть собрание новой лжи и старых басен». Мнение сих нечестивъx, конечно, справедливо ${ }^{21}($ выделено мной - А. Д.).

Я буду неоднократно обращаться к этим словам Пушкина, потому что в них ответ всем измышлениям и всем измыслителям: и Достоевскому, и Соловьеву, и Бердяеву, и нынешним интерпретаторам. Более того: как видим, Пушкин соглашается с «нечестивыми»,

${ }^{21}$ Пушкин А. С. Подражания Корану.//ушикин. Т. 2. C. 210. 
и к числу «нечестивых», «неверных», «малодушных» поэт причисляет себя.

Культурно-идеологическая стихия, из которой рождался Коран, имела сложную структуру. И Аллах, и Мохаммед в Коране постоянно полемизируют с оппонирующими им «нечестивыми». Грязневич обобщает аргументы оппонентов: «Россказни предков!», «Это мы уже слышали от других!». ${ }^{22}$ Я ссылаюсь на это обобщение, чтобы показать, что оценка Пушкиным Корана как «лжи» и «басен» родилась гораздо раньше Пушкина, и что поэт был отнюдь не одинок в своих оценках Священной книги мусульман.

Тем не менее, и это главное в моем эссе, Пушкин написал немало прекрасных стихов на темы, взятые из Корана. Вернемся снова к основополагающему высказыванию Пушкина о Коране. Вот оно, теперь уже в полном виде:

« «ечестивые, пишет Магомет (глава Награды), думают, что Коран есть собрание новой лжи и старых басен». Мнение сих нечестивъх, конечно. справедливо; но, несмотря на сие, многие нравственные истины изложены в Коране сильным и поэтическим образом». ${ }^{23}$ (выделено мной - А. Д.)

Поэзия Корана - вот единственный интерес поэта! И перед судом потомков-присяжных я могу предъявить свидетеля этого интереса - самого Пушкина. Пушкин погружается не в мир «новой лжи и старых басен», а в поэтический мир коранических образов и языка книги.

«Кораническая декламация (слово «коран» буквально значит «декламация», «чтение речитативом») поражает даже не знающего арабский язык... В России впервые это почувствовал А. С. Пушкин, - пишет автор комментария к Корану профессор Рустам Алиев [он] с присущей ему проницательностью почувствовал всю поэтичность и божественное вдохновение коранических стихов». ${ }^{24}$

Еще точнее выразился известный исследователь «Подражаний Корану» Б. В. Томашевский: «Он (Пушкин - А. Д.) «далеко отходил от оригинала и влагал в стихи смысл, часто отсутствующий в подлиннике. Поэтому подражания следует рассматривать как оригинальные стихи Пушкина,

\footnotetext{
${ }^{22}$ Там же.

${ }^{23}$ Пушкин А. С. Подражания Корану.// Пушкин. Т. 2.

C. 210.

${ }^{24}$ Алиев Р. Послесловие.// Коран. С. 730.
}

иногда наполненные автобиографическим содержанием и только стилизованные в духе Корана». ${ }^{25}$

После цитирования высказывания Пушкина о Коране авторитетного мнения Томашевского о пушкинских «Подражаниях» вроде бы становится все ясно: Пушкин отделял поэзию Корана от религии Корана. Но все-таки остается сомнение - может быть прав Достоевский - а разве это возможно? Разве возможно полностью отделить поэзию религиозной книги от ее религиозного содержания? Конечно у Пушкина «цель искусства - искусство» и «цель поэзии - поэзия», но мог ли поэт, используя образы Корана, не перевоплощать «дух своей поэзии» в «дух Корана»? Мог ли он, следуя принципу «цель поэзии - поэзия», не производить религиозно-народнический, идейно-политический продукт, пусть и в поэтической форме?

\section{4. Перевоплощал ли Пушкин «дух свой поэзии» в «дух Корана»?}

Разделяю ответ на этот вопрос на две части. Конечно, надо анализировать каждое стихотворение пушкинского стихотворного цикла, отвечая на вопрос: перевоплощал или не перевоплощал? Но до того, как начать такой анализ, надо понять, что имел ввиду Достоевский, когда утверждал, что Пушкин перевоплощал «дух своей поэзии» в «дух Корана».

Давайте в приведенной выше цитате из «Пушкинской речи» о «духе» «Подражаний Корану» сгруппируем смыслы, через которые Достоевский интерпретировал пушкинское видение Корана и через которые, как он считал, Пушкин подражал Корану:

1) Религиозность интерпретации Корана («Вот рядом с этим религиозным мистицизмом религиозные же строфы из Корана»).

2) Мусульманин, дух мусульманства («Разве тут не мусульманин?»).

3) Дух Корана, его мусульманская специфика («Разве это не самый дух Корана?»).

4) Меч Корана, воинственность мусульманина («Разве это не... меч его (Корана А. Д.)?»).

5) Вера Корана («Разве это... не простодушная величавость веры?»).

${ }_{25}^{25}$ Томашевский Б. В. Примечания. Подражания Корану. //Пушкин. Т 2. С. 425-426 
6) Грозная кровавая сила ислама («Разве это не... грозная кровавая сила ее (веры - А. Д.)?»). ${ }^{26}$

Мне это перечисление будет нужно потом, когда буду обобщать результаты своего исследования. А пока констатирую: эти шесть пунктов ясно показывают, что под «перевоплощением» пушкинской поэзии в «дух Корана» Достоевский понимал ее перевоплощение в некую религиозно-народническую арабскую сущность.

Достоевский в «Пушкинской речи» продолжает: «Нет, положительно скажу, не было поэта с такою всемирною отзывчивостью, как Пушкин, и не в одной только отзывчивости тут дело, а в изумляющей глубине ее, а в перевоплощении своего духа в дух чужих народов, перевоплощении почти совершенном, а потому и чудесном, потому что нигде ни в каком поэте целого мира такого явления не повторялось». ${ }^{27}$ Из этого высказывания еще более видно, еще более режет слух вывод: Достоевский, говоря о перевоплощении пушкинской поэзии в «дух Корана», имел ввиду ее перевоплощение в дух арабского народа эпохи написания Корана. Как оценить эту мысль писателя-идеолога?

Первое. Высказывание Достоевского, воспринимающее «дух чужих народов», как нечто единое, методологически некорректно. Народ в любой стране - явление многоликое. В него входит и консервативная часть населения, количественно основная - та, которая более всего дорожит традицией, воспроизводит народную культуру по схеме простого воспроизводства, не хочет перемен и легко превращается в толпу. В него входит и та часть интеллигенции, которая ориентирована на самокритичное развитие общества, на инновацию и реформы, модернизацию. Личность, независимая от культуры - в определенном смысле тоже народ. Разные части народа несут в себе разный «дух». Разную рефлексию и разную поэзию. Есть поэзия веры и безверия, есть грозная поэзия толпы и предсмертное отчаяние ее жертвы, есть поэзия справедливости идеи агрессии и справедливости защиты от агрессии, есть поэзия рабского поклонения народа тотему и романтической независимости личности от тотемов, есть поэзия реформы

\footnotetext{
${ }_{26}^{26}$ Достоевский Ф.. . «Дневник писателя» на 1880 год. Пушкин (очерк). Произнесено 8 июня в заседании Общества любителей российской словесности.//Достоевский. Т. 26. С. 146.

${ }_{27}$ Там же.
}

и антиреформы и т. д. В народе есть разное, и в различные культурные эпохи это разное по-разному проявляется в разных частях народа. Вот почему высказывание Достоевского, интерпретирующее "дух чужих народов» как нечто единое и однозначное, некорректно.

И второе. О каком «духе чужих народов» говорит Достоевский? Все, все без исключения статьи Достоевского отвечают на этот вопрос однозначно: народ для него - большинство населения, это общинный крестьянин, несущий родовые отношения. И неважно, кто он: араб VI века либо русский XIX века. «Дух общины» - идеал для Достоевского. А русская интеллигенция, пойдя по пути реформ Петра I, от народа оторвалась: «У них (у Запада А.Д.) личность, у нас (у России - А. Д.) общность» - не раз писал Достоевский в статьях и «Дневнике писателя». В Коране, если говорить о его «духе», господствует общинный дух, родовые, соборно-авторитарные отношения людей. И индивидуалист Пушкин, по Достоевскому, в «Подражании Корану» перевоплощал индивидуалистический «дух» своей поэзии в религиозно-народнический «дух» общинного араба VI в.

Достоевский: «Это только у Пушкина, и в этом смысле, повторяю, он явление невиданное и неслыханное, а по-настоящему, и пророческое, ибо... ибо тут-то и выразилась наиболее его национальная русская сила, выразилась именно народность его поэзии, народность в дальнейшем своем развитии, народность нашего будущего, таящегося уже в настоящем, и выразилась пророчески. Ибо что такое сила духа русской народности как не стремление ее в конечных целях своих ко всемирности и ко всечеловечности?». ${ }^{28}$ Перевоплощение «духа» пушкинской поэзии в «дух Корана» как признак ее всемирности - это, по Достоевскому, способность пушкинской поэзии нести в себе силу русской народности как всемирной. Не было еще в этом высказывании Достоевского лозунга о всемирном братстве народов на основе православия, которое он выскажет позже, но уже расчищены к нему подходы.

Я привел три цитаты из Достоевского о народно-религиозной всемирности творчества Пушкина (одну - в предыдущем разделе статьи, и две - в этом). Они не выдернуты из раз-

\footnotetext{
${ }_{28}$ Достоевский Ф. М. «Дневник писателя» на 1880 год. Пушкин (очерк). Произнесено 8 июня в заседании Общества любителей российской словесности.//Достоевский. Т. 26. С. 146-147.
} 
ных мест творчества писателя-идеолога. Они все из его «Пушкинской речи». Причем тексты этих высказываний идут один за другим без каких-либо перерывов. И я привел основополагающую цитату из Пушкина о том, что Коран - собрание «лжи» и «старых басен». Из этих четырех цитат ясно видно, что Пушкин писал свои «Подражания», руководствуясь одной идеологией, а Достоевский, оценивая пушкинские «Подражания» - другой. Фокусом противоречия стали разные представления Пушкина и Достоевского о всечеловечности, о том, что может объединять людей. У Достоевского - способность человека погрузиться в исторически сложившуюся народность-религиозность, жить неразрывной жизнью с тысячелетиями накопленными стереотипами народной культуры. У Пушкина - отказ от родового культурного наследия; это по умолчанию опора на то, что такому наследию противостоит индивидуальность человека, его способность быть независимым от культуры, достоинство способности подняться над ее исторически сложившимися этническими стереотипами. Личность и народ - вот где фокус конфликта между «Пушкиным» и «Достоевским» как двумя образами России.

Я не только не против того, чтобы вслед за Достоевским говорить о всемирной отзывчивости Пушкина. Всемирная отзывчивость Пушкина - это действительно факт его поэзии и гордость России. Но обойти вопрос: на каком основании всемирность? - невозможно. Если на основании смысла личности, то есть способности человека к высокой степени независимости от исторической инерции культуры - мусульманской, христианской, атеистической, европейской, азиатской, то это, я согласен, верно. Потому что независимость личности от тысячелетних стереотипов из века в век усиливается во всем мире и на этом основании формируется на земле универсальная культура личности. Но Достоевский - непримиримый и открытый противник идеи личности. И, говоря о всемирной отзывчивости Пушкина, он имел ввиду другое - всемирную отзывчивость поэта на основе народной архаики, многотысячелетней соборности-авторитарности.

Так какого Пушкина я собираюсь защищать от Достоевского? На суд читателей я выставляю тезис: Пушкин в «Подражаниях Корану» не подражал Корану. Он не подражал. Он писал оригинальную поэзию, главным героем которой был он сам. Это гипотеза. И я собира- юсь ее доказать, анализируя каждое стихотворение его цикла.

\section{5. Первое подражание \\ (переложение суры 91 «Солнце») 29}

Пушкин, как я уже говорил выше, написал цикл «Подражания Корану» в ссылке, в родовом поместье Пушкиных - селе Михайловском. Там он был под постоянным наблюдением отца С. Л. Пушкина, который по поручению полиции перлюстрировал письма сына. ${ }^{30}$ Чтобы избежать контроля, Пушкин переселился в соседнее имение Тригорское,

${ }^{29}$ Сура 91 «Солнце». //Коран. С. 500-501.

зо Пушкин А. С. - Жуковскому В. А. 31 октября 1824 г. Из Михайловского и Тригорского в Петербург: «Милый, прибегаю к тебе. Посуди о моем положении. Приехав сюда, был я всеми встречен как нельзя лучше, но скоро все переменилось: отец, испуганный моей ссылкою, беспрестанно твердил, что и его ожидает та же участь; Пещуров, назначенный за мною смотреть, имел бесстыдство предложить отцу моему должность распечатывать мою переписку, короче быть моим шпионом; вспыльчивость и раздражительная чувствительность отца не позволяли мне с ним объясниться; я решился молчать. Отец начал упрекать брата в том, что я преподаю ему безбожие. Я все молчал. Получают бумагу, до меня касающуюся. Наконец, желая вывести себя из тягостного положения, прихожу к отцу, прошу его позволения объясниться откровенно... Отец осердился. Я поклонился, сел верхом и уехал. Отец призывает брата и повелевает ему не знаться avec ce monstre, ce fils dénaturé... (Жуковский, думай о моем положении и суди.) Голова моя закипела. Иду к отцу, нахожу его с матерью и высказываю все, что имел на сердце целых три месяца. Кончаю тем, что говорю ему в последний раз. Отец мой, воспользуясь отсутствием свидетелей, выбегает и всему дому объявляет, что я его бил, хотел бить, замахнулся, мог прибить... Перед тобою не оправдываюсь. Но чего же он хочет для меня с уголовным своим обвинением? рудников сибирских и лишения чести? спаси меня хоть крепостию, хоть Соловецким монастырем. Не говорю тебе о том, что терпят за меня брат и сестра - еще раз спаси меня. 31 окт. А. П.

Поспеши: обвинение отца известно всему дому. Никто не верит, но все его повторяют. Соседи знают. Я с ними не хочу объясняться - дойдет до правительства, посуди, что будет. Доказывать по суду клевету отца для меня ужасно, а на меня и суда нет. Я hors la loi.

P.S. Надобно тебе знать, что я уже писал бумагу губернатору, в которой прошу его о крепости, умалчивая о причинах. П. А. Осипова, у которой пишу тебе эти строки, уговорила меня сделать тебе и эту доверенность. Признаюсь, мне немного на себя досадно, да, душа моя, - голова кругом идет». // Пушкин. Т. 10. С. 107. 
владелицей которого была Прасковья Александровна Осипова, которой он и посвятил свою поэму.

«Первое подражание» Корану - переложение суры «Солнце». ${ }^{31}$ Но это переложение не просто изложение Пушкиным ее содержания. В этом стихотворении произошли удивительные метаморфозы. Если в суре коранический Аллах обращается к своему Пророку Мохаммеду, то в первом «Подражании» пушкинский Аллах обращается к Пушкину.

Он говорит поэту:

Нет, не покинул я тебя.

Кого же в сень успокоенья

Я ввел, главу его любя,

И скрыл от зоркого гоненья?

Образа «зоркого гоненья» в Коране нет. Пушкинский Аллах имеет ввиду, что Он скрыл, укрыл Пушкина от «зоркого гоненья», то есть от надзора за ним отца поэта. «Сень успокоенья» - это село Тригорское, где поэт получил возможность спокойно работать. Аллах любит Пушкина: «главу его любя». Поэтому легко понять, что последующий свой вопрос Аллах адресует также Пушкину:

Не я ль язык твой одарил

Могучей властью над умами?

Образа «могучей власти» языка «над умами» также нет в суре. И далее призыв Аллаха к Пушкину как поэту-пророку:

Мужайся ж, презирай обман, Стезею правды бодро следуй, Люби сирот, и мой Коран

Дрожащей твари проповедуй.

Ничего коранического не взял Пушкин из суры «Солнце» кроме поэзии.

А вот вторая тема в этой суре, которую разрабатывает Пушкин. Поэта поразила экспрессия клятвы Аллаха, романтическая поэтика ее образов.

\footnotetext{
${ }^{31}$ Пушкин в примечании указывает, что «Переложение первое» написано как переложение суры «Награды».// Пушкин. Т. 2. С. 210. Таково название суры в тексте Корана, переведенного М. И. Веревкиным, которым пользовался Пушкин. В переводе В. М. Похоровой эта сура именуется «Солнце восходящее». В переводе И. Ю. Крачковского, которым я пользуюсь, она называется «Солнце».
}

Вот как это у Аллаха в Коране:

Клянусь солнцем и его сиянием, И месяцем, когда он за ним следует, И днем, когда он его обнаруживает, И ночью, когда она его покрывает, И небом, и тем, что его построило, И всякой душой, и тем, что ее устроило

И внушило ей распущенность еe и богобоязненность! ${ }^{2}$

А вот клятва Аллаха в суре «Город»:

Не клянусь этим городом!..33

Или в суре «Заря»:

Клянусь зарею, и десятью ночами, и четом и нечетом, и ночью, когда она движется! ${ }^{4}$

Или в суре «Ночь»:

Клянусь ночью, когда она покрывает, И днем, когда он засиял, И тем, что создало мужчину и женщину. 35

Или в суре «Завернувшийся»:

Клянусь месяцем!

И ночью, когда она повертывается, И зарей, когда она показывается!36

Пушкин пишет в примечании к своему первому «Подражанию»: «В других местах Корана Алла клянется копытами кобылиц, плодами смоковницы, свободою Мекки, добродетелию и пороком, ангелами и человеком и проч. Странный сей риторический оборот встречается в Коране поминутно».37 Странный сей риторический оборот - натуралистическая специфика азиатской народной культуры, перекочевавшая в Коран - не интересует Пушкина. Его интересует поэзия, которую несет в себе способность Аллаха выразить себя через клятву.

${ }^{32}$ Аяты 1-8, сура 91 «Солнце». //Коран. С. 500.

${ }^{33}$ Аят 1, сура 90 «Город».// Коран. С.499.

${ }_{34}$ Аяты 1-3(4), сура 89 «Заря».// Коран. С. 498.

${ }_{35}$ Аяты 1-3, сура 92 «Ночь».// Коран. С. 501.

${ }_{36}$ Аяты 35(32) -37(34), сура 74 «Завернувшийся».// Коран. С. 479.

${ }^{37}$ Пушкин А. С. Подражания Корану. Примечания.// Пушкин. Т. 2. С. 210-211. 
Прелестна клятва пушкинского Аллаха:

Клянусь четой и нечетой,

Клянусь мечом и правой битвой,

Клянусь я утренней звездой,

Клянусь вечернею молитвой. ${ }^{38}$

«Чета и нечета» следует понимать как «сочетаемое и несочетаемое» (соединение и разделение), то есть «все». Действительно, если уж пушкинскому Аллаху клясться, то «всем».

Еще больше поэзии у Лермонтова. Его Демон в поэме «Демон» также пошел по пути Аллаха Мохаммеда:

Клянусь я первым днем творенья,

Клянусь его последним днем,

Клянусь позором преступленья

И вечной правды торжеством.

Клянусь паденья горькой мукой,

Победы краткою мечтой;

Клянусь свиданием с тобой

И вновь грозящею разлукой.

Клянуся сонмищем духов,

Судьбою братий мне подвластных,

Мечами ангелов бесстрастных,

Моих недремлющих врагов;

Клянуся небом я и адом,

Земной святыней и тобой.

Клянусь твоим последним взглядом,

Твоею первою слезой,

Незлобных уст твоих дыханьем,

Волною шелковых кудрей;

Клянусь блаженством и страданьем,

Клянусь любовию моей... ${ }^{39}$

...Художник в прозаической вещи - пне, ветке, шишке, куске коры, куче мха, морской волне, облаке, солнце, в идеях ада и рая, в религиозных текстах и идеях находит заложенную в них возможность поэзии и создает поэтический шедевр, в котором от первоначального материала остается лишь тень... В пушкинском переложении суры «Солнце», поэтическом, нерелигиозном, лиричном и очень личном, ничего не осталось от религиозности Корана. Это вполне самостоятельное художественное произведение.

Восхитившись экспрессией клятв Аллаха и освободившись с помошью Аллаха и соседки Осиповой от опеки отца, Пушкин купается в

${ }^{38}$ Пушкин А. С. Подражания Корану. // Пушкин. T. 2. C. 204 .

39 Лермонтов М. Ю. Демон.// Лермонтов М. Ю. Собр. соч. в 4-х т. М. Изд-во «Правда». 1949 г. Т. 2. С. 435. собственной поэзии. Рождается «Первое подражание» Корану - романтическая увертюра к великолепному стихотворному циклу.

\section{6. Второе подражание (переложение суры 33 «Сонмы») ${ }^{40}$}

Аллах: «О жены пророка! Кто совершит из вас явную мерзость, той будет наказание вдвойне». ${ }^{41}$ Аллах: «О жены пророка! Вы - не таковы, как какая-нибудь из женщин. Если вы богобоязненны, то не будьте мягки в словах, чтобы не возжелал тот, в сердце которого болезнь, и говорите слово ведомое». ${ }^{42}$ Аллах: «О пророк. Мы разрешили тебе твоими женами тех, которым ты дал их награду, и тех, которыми овладела твоя десница из того, что даровал Аллах (Аллах в Коране часто говорит о себе в третьем лице - А. Д.) тебе в добычу, и дочерей твоего дяди со стороны отца, и дочерей твоих теток со стороны отца, и дочерей твоего дяди со стороны матери, и дочерей твоих теток со стороны матери, которые выселились вместе с тобой, и верующую женщину, если она отдала самое себя пророку, если пророк пожелает жениться на ней, - исключительно для себя, помимо верующих»43. Аллах: «Мы знаем, что Мы установили для них относительно их жен и того, чем овладели десницы их, для того, чтобы не было на тебе стеснения ${ }^{44}$.

Из исторической литературы видно, что вся эта дидактика действительно была необходима в арабском мире в VII в., чтобы защитить женщину, девочку, ее права, от произвола мужчины, но и женщина должна была ограничить свое право свободно выбирать себе мужчину. Аллах Мохаммеда жестко наводил порядок в арабских племенах. Это была не легкая работа. И тема для поэзии не очень подходящая.

Но какую прелесть из этих нудных и полезных аятов сотворил пушкинский Аллах, стилизуя свою речь под наставления Корана:

О жёны чистые Пророка.

От всех вы жён отличены:

Страшна для вас и тень порока.

Под сладкой сенью тишины

Живите скромно: вам пристало

Безбрачной девы покрывало.

${ }^{40}$ Сура 33 «Сонмы». // Коран. С.343-350.

${ }^{41}$ Аят 30, сура 33 «Сонмы». // Коран. С.346.

${ }^{42}$ Аят 32, сура 33 «Сонмы» // Коран. С. 346.

43 Аят 49(50), сура 33 «Сонмы» // Коран. С. 348.

${ }^{44}$ Аят 50, сура 33 «Сонмы» // Коран. С. 348. 
Храните верные сердца

Для нег законных и стыдливых,

Да взор лукавый нечестивых

Не узрит вашего лица!

А вы, о гости Магомета!

Стекаясь к вечери его,

Брегитесь суетами света

Смутить Пророка Моего.

В паренье дум благочестивых,

Не любит он велеречивых,

И слов нескромных и пустых:

Почтите пир его смиреньем,

И целомудренным склоненьем

Его невольниц молодых. ${ }^{45}$

Эти поэтические строки - не все содержание суры. Лишь два сюжета: о верности жен и наложниц пророка, их поведении на пире и поведении гостей-мужчин на пире в отношении женщин пророка.

Ю. И. Крачковский, переводчик Корана, считал, что, несмотря на поэтические достоинства Корана, перевод его текста в стихотворной форме невозможен, а поэтическое переложение Корана недопустимо. Пушкин делает невозможное и недопустимое. Излагая отдельные сюжеты коранического текста в поэтической форме, он делает их прекрасными. Но... специфическим способом - отодвинув на задний план поэтической рефлексии всю кораническую догматику.

Посудите сами:

1. «О жёны чистые Пророка... Страшна для вас и тень порока», - пишет Пушкин. Никаких угроз наказания. Никакого разбора родственных отношений. Склоки ему не интересны. А интересны ему образы «жены чистые» и «тень порока». Он их использовал и в «Евгении Онегине»: «А вы о Девы без упрека,// Которых даже тень порока// Страшит сегодня, как змия...» ${ }^{46}$. Слово «Девы » написал с большой буквы и курсивом, а «Девы без упрека» выделил курсивом, возводя происхождение этих слов к «женам чистым».

2. Пушкин увидел поэзию во встрече двух смирений. «Почтительное смирение» гостей Пророка - хозяина пира, на котором присутствуют его молодые невольницы, и «целомудренное склонение (поведение - А. Д.)» этих невольниц на пире, где полно мужчин.

${ }^{45}$ Пушкин А. С. Подражание Корану. // Пушкин. C. 204-205.

${ }^{46}$ Пушкин А. С. Евгений Онегин. Ранние редакции. Глава третья.// http://www.rvb.ru/pushkin/o1text/o4o negin/o2edit/0853.htm
Пушкинский Аллах: «Почтите пир его смиреньем,// И целомудренным склоненьем// Его невольниц молодых». Разве в этом «нельзя, но хочется» - не поэзия реальной жизни?

Пушкин с элементом иронии комментирует: ««Мой пророк, прибавляет Алла, вам этого (требование смирения перед недоступностью невольниц - А. Д.) не скажет, ибо он весьма учтив и скромен; но я не имею нужды с вами чиниться» и проч. Ревность араба так и дышит в сих заповедях».47 За установлениями Аллаха Пушкин увидел след страсти, в пушкинских стихах дышит поэзия реальной жизни.

3. Аллах: «О, пророк, скажи своим женам: «Если вы желаете ближней жизни и ее прикрас, то приходите: я дам вам насладиться и отпущу прекрасным способом. А если вы хотите Аллаха и Его посланника и последнего жилища, то Аллах уготовал добродеющим из вас великую награду» ${ }^{8}$. Пушкина не интересует ни встреча «добродеющей» женщины с Аллахом. Ни величина Его награды женщине за веру. Ни рай на земле в жилище пророка. Его интересует прелесть отношений между мужчиной и женщиной, нега физической близости мужа и жены. И он вкладывает в уста Аллаха повеление женам пророка безрелигиозное: «Храните верные сердца// Для нег законных и стыдливых».

Перечитайте текст «Второго подражания» - бездна поэзии и никакой религиозности!

\section{7. Третье подражание. (переложение сур 80 «Нахмурился» ${ }^{49}$, 22 Хадж $^{50}$ и других).}

Аллах: «Аллах нахмурился и отвернулся от того, что подошел к нему (к пророку - А. Д.) слепой» ${ }^{1}$. Человек этот был Абдалла ибн Умм Мактум. Он из знатного рода, впоследствии правитель Медины ${ }^{52}$. Был ли он слепым? В доступных мне комментариях Корана ответа на этот вопрос я не нашел. Но я уверен: он не слепой. Во-первых, слепой вряд ли мог стать правителем Медины. Во-вторых, «слепой», «слепец» повсеместно в Коране - значит не видящий пути, истины, не принимающий веры. Аллах в Коране называет его «нечестивым».

\footnotetext{
47 Пушкин А.С. Подражания Корану. // Пушкин. Т. 2. C. 211.

${ }^{48}$ Аят 28, сура 33 «Сонмы».// Коран. С.346.

49 Сура 80 «Нахмурился».// Коран. С.489-490.

${ }^{50}$ Сура 22 «Хадж».// Коран. С.274-281.

${ }^{11}$ Аяты 1-2, сура 80 «Нахмурился». // Коран. С.489.

${ }^{52}$ Комментарии. Сура 8о.// Коран. С.638.
} 
Не случайно, вся сура «Нахмурился» - это спор «зрячего» Мохаммеда со «слепцом» Абдаллой.

Пушкин, по-видимому, тоже понимал Абдаллу не как слепого, а как неверующего. По крайней мере, в «Третьем подражании» слова «слепец», «носитель порока», «строптивый», «нечестивый» синонимичны. О том, что мое понимание слова «слепой» совпадает с пушкинским, говорит и стихотворная заметка поэта на полях его так называемой «второй масонской тетради», где он делал наброски своих «подражаний» (верхняя часть, л. 18 об.):

Слаб и робок человек

Слеп умом - и все тревожит. ${ }^{53}$

От этой заметки легко перейти к явлению «слепого умом», «слепца»:

Смутясь, нахмурился Пророк

Слепца послышав приближенье:

Бежит, да не дерзнет порок

Ему являть недоуменье.

«Слепец» не верит ни в Аллаха, ни в конец света, ни в то, что человек грешен. Он горд. Строптив. Порочен. Носитель дерзкого недоуменья-неверия. Осмеливается спорить. Поэтому Мохаммед «бежит» от спора с «порочным», «строптивым», «нечестивым» слепцом, а Аллах «нахмурился и отвернулся». Коранический Аллах: «Напоминание, - и кто пожелает, его вспомнит, - в свитках почтенных, возвышенных. Очищенных руками писцов. Почтенных, благих»54. «Почтенные свитки», «списки» - это Коран, небесная книга. В ней истина в последней инстанции. Кто смеет спорить с истиной?

А вот пушкинский Аллах:

С небесной книги список дан

Тебе, Пророк, не для строптивых;

Спокойно возвещай Коран,

Не пробуждая нечестивых!

Вспомним из «Евгения Онегина»: «и не спорь с глупцом», то есть не побуждай к спору строптивых и нечестивых. Великолепна арабская пословица: «Не спорь с дураком, а то люди могут не увидеть разницы между вами».

\footnotetext{
53 Фомичев С. А. «Подражания Корану». Генезис, архитектоника и композиция цикла // http:/feb-web. $\mathrm{ru} /$ feb/pushkin/serial/v81/v81-022-.htm

${ }_{54}^{4}$ Аяты 11-15, сура 80 «Нахмурился». // Коран. С.489.
}

Почему Пушкина привлек образ «слепого умом», «слепца»? Этот образ позволяет говорить о главном в жизни человека - о смерти и бессилии человека перед ней. Это безусловно предмет поэзии. Поскольку смерть - Абсолют, и поэзия, и религия говорят о ней примерно одними и теми же словами. Вот как это у Пушкина:

Почто ж кичится человек?
За то ль, что наг на свет явился?
Что дышит он не долгий век,
Что слаб умрёт, как слаб родился?
За то ль, что Бог и умертвит
И воскресит его - по воле
Что с неба дни его хранит
И в радостях и в горькой доле
За то ль, что дал ему плоды,
И хлеб, и финик, и оливу,
Благословив его труды,
И ветроград, и холм, и ниву?

Это религия? Нет. Это поэзия общечеловеческой трагедии конечности бытия, конца света, и она изначально узурпирована поэтами и пророками. Но сегодня поэзия и религия по-разному чувствуют себя, говоря о смерти.

Век за веком религия в этой теме теряет свои позиции - ведь самая истовая приверженность религиозному обряду не может изменить динамику жизни и смерти человека как абсолютный закон бытия. А поэзия не теряет. Потому что не обещает бессмертия. Она лишь описывает трагедию человека. Религия заявляет, что может отменить эту трагедию и поэтому все более обнаруживает свою неубедительность. А поэзия в каждом новом художественном произведении все глубже проникает в сущность трагедии, а значит, в сущность бытия. Два образа этой трагедии: религиозный - Корана и поэтический - «Подражаний Корану», взаимопроникая в словах, но не взаимопроникая по сути, порождают две противоположные самости бытия. Это самость Аллаха, удовлетворяющая потребность человека верить и поклоняться, и самость поэта, удовлетворяющая потребность человека самокритично превращать свою способность к рефлексии в проблему. Это две противоположные природы человеческого в человеке и два отношения к своей трагедии.

Последние два процитированные выше пушкинские четверостишия навеяны многими сурами. Например, сурой «Хадж»: «В тот день, как вы его (страшный суд, или конец 
света - А. Д.) увидите, каждая кормящая забудет того, кого кормила, а каждая обладательница ноши сложит свою ношу. И увидишь ты людей пьяными, но они не пьяны. Но наказание Аллаха - сильно». ${ }^{55}$ Никто не знает, будет ли конец света и как он будет выглядеть. Поэты знают. Мохаммед и Пушкин в их числе:

Но дважды ангел вострубит;

На землю гром небесный грянет:

И брат от брата побежит,

И сын от матери отпрянет

И все пред богом притекут

Обезображенные страхом

И нечестивые падут

Покрыты пламенем и прахом.

К. Ф. Рылеев (1795 - 1826), поэт, общественный деятель, один из пяти казненных руководителей декабрьского восстания 1825 г., друг Пушкина писал ему в Михайловское в апреле 1825 г.: «Лев (Лев Сергеевич Пушкин, брат А. С. Пушкина - А. Д.) прочитал нам несколько твоих новых стихотворений. Они прелесть; особенно отрывки из Алкорана. Страшный суд ужасен. Стихи

И брат от брата побежит,

И сын от матери отпрянет

превосходны»..$^{6}$

Поэт не создает религиозного продукта поэтическими средствами. Он, дотрагиваясь до главного в рефлексии - временности жизни человека - создает произведение искусства. И не делит людей на «слепцов» и «зрячих».

Что бессмертно в фресках Микеланжело Буонарроти (1475 - 1564) в Ватикане? Содержание библейского мифа, изображенное на своде Сикстинской капеллы, или поэзия творчества великого мастера? Весь мир вот уже пятьсот лет ходит смотреть на это шедевр. Не для того, чтобы узнать что-то о христианстве, а чтобы приобщиться к великому искусству. Что бессмертно в прелюдиях и фугах Баха, в «Реквиеме» Моцарта, в Девятой симфонии Бетховена, в Пятой симфонии Чайковского? Эти произведения не фальшивят, обещая бессмертие, а уникальным образом говорят о величии и ничтожестве человеческого бытия.

\footnotetext{
${ }_{55}$ Аят 2, сура 22 «Хадж». // Коран. С. 274.

${ }^{6}$ Рылеев К.Ф. - Пушкину А.С. Конец апреля 1825 г. Петербург//Гордеев К. Пушкин. Подражания Коранy.// Cм. http://www.tatworld.ru/article.shtml?article= 240\&section $=0$ \&heading $=0$
}

Временность жизни - основная трагедия человека. Пушкин в «Третьем подражании» уникальными стихами (прав Рылеев) воспроизводит художественный образ этой трагедии.

\section{8. Четвертое подражание. (Переложение аята 260(258) суры Корова) ${ }^{57}$}

Спор Ибрахима (Авраама) с языческим царем Бабиля (Вавилона) Н`Амрудом (Нимродом): «Разве ты не видел того, кто препирался с Ибрахимом о Господе его за то, что Аллах дал ему власть? Вот сказал Ибрахим: «Господь мой, Который оживляет и умерщвляет». Сказал он: «Я оживляю и умерщвляю». Сказал Ибрахим: «Вот Аллах выводит солнце с востока, выведи же его с Запада». И смущен был тот, который не верил: Аллах ведь не ведет прямо людей неправедных!»..$^{8}$

Спор о пределах могущества Бога и человека. Вечная тема. Какой поэт не соблазнится ею! И на Востоке, и на Западе. Пушкин в «Четвертом подражании» усиливает полемический момент коранического текста тем, что с царем спорит не только один из пророков Аллаха, но в спор включается и сам Аллах. «Четвертое подражание» начинается тем, что Пушкин перелагает этот сюжет, делая себя его участником и все время меняя подлежащее.

Пушкин Аллаху:

С тобою древле, о всесильный.

Могучий состязаться мнил,

Безумной гордостью обильный;

Но ты, господь, его смирил.

А далее полемика пушкинского Аллаха и царя Нимрода в прямой речи:

Ты рек: я миру жизнь дарую,

Я смертью землю наказую,

На все подъята длань моя.

Я также, рек он (Н’Амруд - А. Д.), жизнь дарую,

И также смертью наказую:

$\mathrm{C}$ тобою, боже, равен я.

\section{Вывод Пушкина:}

Но смолкла похвальба порока

От слова гнева твоего;

57 Аят 260 (258), сура 2 «Корова». // Коран. С. 56.

${ }^{58}$ Аят 260 (258), сура 2 «Корова». // Коран. С. 56. 


\section{Пушкинский Аллах:}

Подъемлю солнце я с востока;

С заката подыми его!

Какая мощь содержания и лаконичность формы.

Почему этот сюжет так привлек Пушкина? Он ставит общечеловеческий вопрос, характерный для ренессансной мысли: в чем смысл человека в мироздании? Чтобы продолжить наши рассуждения, нам для сравнения понадобятся мысли авторитетного представителя эпохи Возрождения.

Обратимся к «Речи о достоинстве человека» Джованни Пико дела Мирандолы (Pico della Mirandola,1463-94), итальянского мыслителя Возрождения, представителя раннего гуманизма, в философствовании которого этот вопрос был одним из центральных. Мирандола вкладывает в уста Бога монолог, обращенный к библейскому Адаму, первому человеку:

«Не даем мы тебе, о Адам, ни определенного места, ни собственного образа, ни особой обязанности, чтобы и место, и лицо и обязанность ты имел по собственному желанию, согласно твоей воле и твоему решению... Я ставлю тебя в центре мира, чтобы оттуда тебе было удобнее обозревать все, что есть в мире. Я не сделал тебя ни небесным, ни земным, ни смертным, ни бессмертным, чтобы ты сам, свободный и славный мастер, сформировал себя в образе, который ты предпочтешь. Ты можешь переродиться в низшие, неразумные существа, но можешь переродиться по велению своей души и в высшие божественные...».

И далее Мирандола говорит уже от себя: «Рождающемуся человеку Отец дал семена и зародыши разнородной жизни и соответственно тому, как каждый их возделает, они вырастут и дадут в нем свои плоды. И если зародыши растительные, то человек будет растением, если чувственные, то станет животным, если рациональные, то сделается небесным существом, а если интеллектуальные, то станет ангелом и сыном Бога. А если его не удовлетворит судьба ни одного из творений, то пусть возвратится к центру своего единообразия и, став единым с Богом-духом, пусть превосходит всех в уединенной мгле Отца, который стоит над всем».59

59 Джованни Пико делла Мирандола. Речь о достоинстве человека. Пер. с ит. Л.Брагиной.// http://www. opentextnn.ru/man/?id=1812
Что в этой речи главное для нашего исследования? Мысль, что человек может нести в себе «высшее божественное», стать «небесным существом», «сыном Бога», «ангелом», «единым с Богом-духом» и вместе с БогомОтцом «стоять над всем» «в уединенной мгле Отца», если захочет. Другими словами, он может нести в себе богочеловеческое, из которого исходит Святой дух (filioque), и в этом смысле быть равным Богу. Эта гуманистическая мысль пронизывает Новый Завет и художественное творчество Ренессанса...

Вернемся к пушкинскому «Четвертому подражанию». В нем спорят, с одной стороны, пророк Ибрахим (Авраам) и Аллах, с другой, человек, который опирается на аргументы европейского Ренессанса. Мне могут возразить: как это - в Коране, и вдруг европейский человек? Да, это так. Не только в «Четвертом подражании», но по всему тексту Корана идет полемика Аллаха с «неверными». И гуманистическая позиция некоторых «неверных» напоминает позицию мыслителей Ренессанса: «Я оживляю и умерщвляю», то есть равен Аллаху, - говорит царь Вавилона Н'Амруд, оппонент Ибрахима и Аллаха в суре «Корова»; «С тобою, боже, равен я», - имея ввиду этот же сюжет, говорит пушкинский Н’Амрод в «Четвертом подражании».

Конечно, участники полемики азиатский царь и философ европейского Возрождения - не одно и то же, даже если они слова произносят почти одни и те же. Да и коранический Аллах - отнюдь не новозаветный Иисус. Если Мирандола утверждает самость человеческого в человеке, то коранический Ибрахим решает противоположную задачу. Он хочет «смутить» «кичащегося» человека: если ты, человек, заявляешь, что равен Аллаху, измени законы природы, которые Он установил; если не можешь, значит, ты Ему не равен: «И смущен был тот, который не верил». Мог бы Мирандола сказать такие слова? Мог. Легко. Но не произнес. Потому что ему это было не нужно, потому что задача его была иная - не принизить значимость человека перед Богом, а поднять до уровня Бога. Такова новозаветно-ренессансная постановка вопроса о значении человека в мироздании.

«Тут весь мусульманин!», - восклицает Достоевский в «Пушкинской речи» о «Подражаниях Корану». Не верно. Ислам ни в одной стране ни в одну эпоху не ставил вопрос о том, что человек равен Абсолюту, ни в каком смысле, а новозаветный гуманизм 
эпохи Ренессанса поставил. Может ли человек изменять законы природы, установленные Создателем? - это неубиваемый вопрос авраамических религий человеку европейского Возрождения, который Создателя еще не успел заменить эволюцией. Пушкин увидел в полемике Ибрахима и Н’Амруда близкое, «родное», хорошо ему известное из истории Европы - постановку вопроса о смысле человеческого в человеке. Но, увидев в Коране эту тему как проблему самопознания человека, он - какое разочарование для идеологических интерпретаторов! - не разрешал ее ни по-азиатски, ни поевропейски, ни религиозно, ни атеистически, ни в духе Ренессанса, ни в духе Корана, ни против духа Корана...

Он создавал поэзию, цель которой - поэзия.

\section{9. Пятое подражание (переложение сур «Пророк», «Сияние», «Создатель», «Брашно»)}

В пятом «Подражании» излагается геоцентрическая концепция физики Земли, господствовавшая в умах людей в эпоху написания Корана. Она излагается во многих сурах.

Вот первая строфа пятого подражания в пушкинских стихах:

Земля недвижна; неба своды,

Творец, поддержаны Тобой,

Да не падут на сушу воды

И не подавят нас собой.

Пушкин с позиции гелеоцентрической концепции Вселенной Коперника, отбросившей устаревший геоцентризм, пишет в комментарии к этому четверостишью: «Плохая физика; но зато какая смелая поэзия!» ${ }^{60}$.

И далее, отодвигая «плохую физику» в сторону, разрабатывает «смелую поэзию», погружаясь в музыку отношений Аллаха, который правит миром, и прозревающего к истине человека. В «смелой поэзии» «Пятого подражания» рождается гимн жизни.

Зажёг Ты солнце во вселенной,

Да светит небу и земле,

Как лён, елеем напоенный,

В лампадном светит хрустале.

Творцу молитесь; Он Могучий:

Он правит ветром; в знойный день

${ }^{60}$ Пушкин А. С. Подражания Корану.// Пушкин. Т. 2. C. 211.
На небо насылает тучи;

Даёт земле древесну сень.

Он милосерд: Он Магомеду

Открыл Сияющий Коран,

Да притечём и мы ко свету

И да падёт с очей туман.

В чем «смелость» этой поэзии? Проповедник говорит язычникам о том, что Аллах «зажег солнце..., правит ветром..., тучами, открыл Мохаммеду Сияющий Коран». И призывает всех «прозреть». Смело. В этих сурах Корана Пушкину было все равно: устарела геоцентричная система мироздания как основание ислама или нет. Его увлек восторг проповедника, сила его убежденности, поэзия его проповеди.

Пушкин и я вместе с ним: «Плохая физика!». Конечно, плохая. Но какая это имеет значение?

«Зато какая смелая поэзия!».

\section{0. Шестое подражание. (переложение суры 48 «Победа» ${ }^{61}$ )}

Аллах (о себе в третьем лице): «Оправдал Аллах Своему посланнику видение по истине: «Вы непременно войдете в запретную мечеть, если угодно Аллаху, в безопасности, обрив головы и укоротив, не боясь!». Он знал то, чего вы не знали, и утвердил до этого близкую победу». ${ }^{62}$

Пушкин:

Недаром вы приснились мне

В бою с обритыми главами,

С окровавленными мечами,

Во рвах, на башне, на стене.

Если «вы» с «обритыми головами» в Коране - единомышленники Мохаммеда, которым Аллах «даровал явную победу», ${ }^{63}$ и они «войдут в запретную мечеть», то кто «вы» с «обритыми головами» у Пушкина? Комментарий к «Шестому подражанию» я начинаю с того, что обращаюсь к мнению Б. В. Томашевского: «Переложению придан такой характер, чтобы его можно было понять, как изображение бу-

${ }^{61}$ Сура 48 «Победа».// Коран. С. 418-421.

62 Аят 27, сура 48 «Победа».//Коран. С. 421. 1) Аль-

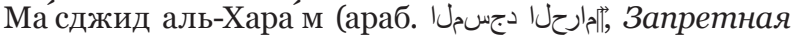
(заповедная) мечеть) - главная мечеть, во внутреннем дворе которой находится Кааба. Расположена в Мекке в Саудовской Аравии. Разрешение войти в запретную мечеть - это награда Аллаха человеку за веру. 2)мусульманин, совершающий хадж, бреет голову. 3) «Укоротить» - значит укоротить время намаза. ${ }^{63}$ Аят 1, сура 48 «Победа».//Коран. С. 418 
дущей победы единомышленников поэта» ${ }^{64}$ декабристов. Мне вывод о декабристах нравится. Я хочу принять его. Встаю на место Томашевского, задаю вопросы и вместе с ним на них отвечаю.

Первый вопрос: Кто такие - «Вы»? Единомышленники Пушкина.

Второй вопрос: Почему «с обритыми главами»? Потому что мусульмане, совершая хадж, брили голову. И вообще, бритая голова мусульманина - признак приобщения к высшему уровню веры в Аллаха. Образ единомышленников поэта с «бритыми головами» - будущих декабристов - признак того, что они свято верили в дело, которому посвятили жизнь.

Третий вопрос: Почему «приснились»? Единомышленники - друзья Пушкина. Поэт хочет и не может с ними встретиться, потому что находится в в ссылке. Они в снах и стихах поэта.

Четвертый вопрос: Почему «недаром»? Потому что русский поэт читает Коран, и в нем говорится о торжестве арабского поэта, победившего в борьбе с врагами, и о его падших единомышленниках. После чтения в Коране этого сюжета Пушкину приснились его друзья-декабристы, готовящие восстание в России. Сон случился «недаром»: будет победа в смертельной схватке и будут жертвы. Пушкин, используя восточные образы, говорит о торжестве своих друзей в этой победе:

Внемлите радостному кличу,

O, дети пламенных пустынь!

Ведите в плен младых рабынь,

Делите бранную добычу!

Вы победили: слава вам.

И вторая мысль суры «Победа» и пушкинского «Шестого подражания». И из этой мысли пятый вопрос: кто такие - «малодушные», которые остались дома и не присоединились к сражавшимся.

Вот черновой вариант первой строфы:

Недаром вы приснились мне

В бою с обритыми главами,

Во рву, на башне, на стене

Гремящих острыми мечами

Вам бог победу даровал

[Гоните робких, похотливых $]^{65}$

${ }^{64}$ Томашевский Б. В. Подражания Корану.// Пушкин. Т. 2. Примечания. С. 426.

${ }^{65}$ Фомичев С. А. «Подражания Корану». Генезис, архитектоника и композиция цикла // http://feb-web. ru/feb/pushkin/serial/v81/v81-022-.htm
Появляется образ «малодушных» как «робких, похотливых». Они никогда не войдут в запретную мечеть. И теперь после победы, - говорит коранический Аллах в суре «Победа», - «ты видишь их преклоняющимися, падающими ниц. Они ищут милости от Аллаха и благоволения» ${ }^{66}$. Они хотят разделить с победителями славу и добычу. Аллах: «Скажут оставленные дома, когда вы отправляетесь к добыче, чтобы взять ее: «Оставьте нас следовать за вами!». Они желают переменить слово Аллаха. Скажи: «Вы никогда не последуете за нами»». ${ }^{67}$

Пушкин:

Вы победили: слава вам, А малодушным посмеянье! Они на бранное призванье Не шли, не веря дивным снам.

Прельстясь добычей боевою, Теперь в раскаяньи своем Рекут: возьмите нас с собою;

Но вы скажите: не возьмем.

Если поставить рядом ответы на все поставленные вопросы, то я начинаю понимать Томашевского и соглашаться с его заключением, что Пушкин мог писать о будущей победе его друзей. Томашевский меня окончательно убеждает, когда ссылается на пушкинское четверостишье, которое было приписано автором после слов «Не шли, не веря дивным снам» и которое так и не появилось в печати:

Они («малодушные» - А. Д.) твердили, пусть виденья

Толкует хитрый Магомет,

Они ума его (творенья),

Его ль нам слушать - он поэт!

Поэты - не те люди, которым обыденное сознание способно верить. Но теперь, когда «малодушные», не пошедшие за победителями, "рекут: возьмите нас с собою», пушкинский Аллах советует Пушкину и его победившим единомышленникам: «Скажите: не возьмем». К. Ф. Рылеев, прочитав «Подражания Корану», пишет Пушкину: «Стихи превосходны. «Страшный суд» - это суд над теми, кто, спрятавшись от борьбы, после победы явится за своей долей добычи:

${ }^{66}$ Аят 29, сура 48 «Победа».// Коран. С. 421.

${ }^{67}$ Аят 15, сура 48 «Победа».// Коран. С. 420. 
Прельстясь добычей боевою,

Теперь в роптании своем

Рекут: возьмите нас с собою;

Но вы скажите: не возымем». ${ }^{68}$

Почему «не возьмем»? Пушкин предвидит события. Слишком много жертв. В его поэтической рефлексии возник образ падших за правое дело:

Блаженны падшие в сраженьи:

Теперь они вошли в эдем

И потонули в наслажденьи,

Не отравляемом ничем.

Несомненна связь «Шестого подражания» с сурой 48. Но еще более несомненен вывод: если в центре суры спор Аллаха с неверными и «малодушными», то у Пушкина главное (прав Томашевский) - поэзия восторга победителей в будущем антисамодержавном восстании и скорбь по тем, кто падет в этой борьбе.

Вот так, господа. Не мог Пушкин писать открыто о своих симпатиях к будущим декабристам и о своем презрении к тем, которые отстранились от их борьбы. Но поэт использовал сюжеты Корана и написал, что хотел. Он писал о России, о русских людях, их борьбе. И будущие декабристы легко расшифровывали стихи поэта.

\section{1. Седьмое подражание. (переложение сур $73-74$ «Завернувшийся» ${ }^{69}$ )}

Аллах: «О, завернувшийся (робкий, боязливый - А. Д.)! Встань и увещевай! И Господа твоего возвеличивай! И одежды твои очисть! И скверны беги! И не оказывай милость, стремясь к большему! И ради Господа твоего терпи!..».70 Аллах: «О, завернувшийся! Простаивай ночь, если не немного, - половину ее, или убавь от этого немного, или прибавь к этому и читай Коран чтением». ${ }^{71}$

Пушкин из этой проповеди делает стихи:

\footnotetext{
${ }^{68}$ Рылеев К. Ф. - Пушкину А. С. Конец апреля 1825 г. Петербург. // Гордеев К. http://www.tatworld.ru/article. shtml?article $=240 \&$ section $=0$ \&heading $=0$

${ }^{69}$ В других переводах Корана сура «Завернувшийся» переводится как «Робкий».

7о Аяты 1(1) - 7(7), сура 74 «Завернувшийся».// Коран. C. 478 .

${ }^{71}$ Аяты 1(1) - 4(4), сура 73 “Завернувшийся». // Коран. C. 477.
}

\author{
Восстань, боязливый: \\ В пещере твоей \\ Святая лампада \\ До утра горит. \\ Сердечной молитвой, \\ Пророк, удали \\ Печальные мысли, \\ Лукавые сны! \\ До утра молитву \\ Смиренно твори; \\ Небесную книгу \\ До утра читай!
}

Почему Пушкин увлекся, читая Священную книгу мусульманина? Я спросил себя: а я могу увлечься чтением Корана? Задав себе этот вопрос, я начал читать Коран, просто читать, не ставя перед собой никакой задачи. Смогу или не смогу?

Смысл Корана я не сразу уловил. Какое-то бесконечное повторение одного и того же. Постоянные объяснения Аллаха человеку, почему он должен верить в Его всесилие. Бесконечные угрозы неверующим. И бесчисленные угрозы мести Аллаха, если человек изменит своей вере. Примерно так воспринимал я Коран, когда читал его впервые. Это угнетает, да и скучно. Но подавив в себе первую неприязнь, я заставил себя не торопиться и вчитываться в тексты аятов. И постепенно что-то изменилось: я почувствовал, что что-то завораживает, не дает бросить чтение, хотя ничего полезного для себя я там так и не нашел, сколько не искал. Хотелось читать и узнать, чем же закончится этот страстный и странный монолог, произносимый то Аллахом, то Пророком. И после некоторого самоанализа начал понимать - прав Пушкин: Коран - это не только собрание «новой лжи и старых басен». Это - поэзия: необычная ритмика, яркие резкие образы, полутонов почти нет, неевропейская мелодия. Гармония льется из смысла всеобщего, но прослышивается лишь через способность отличить поэтическое от религиозного. Сегодня идея Аллаха, Бога, Неба, Пути как единого всеобщего рушится во всем мире, дробится на миллиарды личных всеобщих. Верующим и неверующим людям все меньше нужна религия - одна на всех. Но поэтическое мышление Аллаха в Коране бессмертно. Содержание почти ушло, а поэзия осталась. Поэзия религиозного реликта, клянущегося копытами кобылиц, захватывает. Способность дотронуться до истины, которая презентует себя Абсолютом, но жива лишь как музейный экспонат, увлекает интеллектуальностью про- 
цесса познания, не дает прервать чтение и отложить на потом. И в конце концов ритмика декламации, странность поэтических образов уже не раздражают, а как-то умиротворяют, гонят «печальные мысли», «лукавые сны». И о себе и о Пушкине хочется сказать лермонтовскими словами: «Тогда смиряется души моей тревога,// Тогда расходятся морщины на челе, - // И счастье я могу постигнуть на земле, // И в небесах я вижу бога»... Источник умиротворения не в Аллахе и не в Коране, а в себе. Но это и неважно...

Пушкин читал Коран ночами, запоем, при свете свечи, до утра. Он искал в коранических текстах искусство и писал стихи. Он пил поэзию. Жил ею.

И я. Представляя Пушкина живущим в ссылке в псковской глуши, сходящим с ума от надсмотра полиции и отца, от некончающихся осенне-зимних ночей, сугробов и одиночества, я перефразировал бы его «Седьмое подражание» и отправил бы его опальному поэту:

\author{
Не бойся, поэт. \\ В келье твоей \\ Святая свеча \\ До утра горит. \\ Словом поэзии \\ Ты удали \\ Печальные мысли, \\ Лукавые сны! \\ До утра стихи \\ Дерзая, твори. \\ Небесный Коран \\ До утра читай!
}

\section{2. Восьмое подражание. (переложение аятов многих сур)}

В восьмом подражании речь идет о закяте. Закят или подаяние - не милостыня и не любезность для сирот и бедных, это налог братства. Закят связан с правами бедных и слабых на часть имущества богатых. Имущество человека - достояние Аллаха, который повелевает богатым наделять бедных чемнибудь из своего имущества, каким наделил их Аллах. Милостыня - это доброе слово, сочувствие в горе, любая помощь и услуга. Закят появился гораздо раньше ислама. Это способ жить родовой общиной. Религия лишь взяла этот принцип на вооружение и сакрализовала его.

Пушкин написал «Восьмое подражание» как стихотворное наставление «любить сирот»:
Торгуя совестью пред бледной нищетою, Не сыпь своих даров расчётливой рукой: Щедрота полная угодна небесам.

В день грозного суда, подобно ниве тучной, О сеятель благополучный!

Сторицею воздаст она твоим трудам.

Но если, пожалев трудов земных стяжанья, Вручая нищему скупое подаянье, Сжимаешь ты свою завистливую длань, -

Знай: все твои дары, подобно горсти пыльной, Что с камня моет дождь обильный,

Исчезнут - Господом отверженная дань.

Аллах отвергает закят, если даешь с расчетом, и принимает его, если даешь щедро. Благодарность Аллаха человеку за щедрый закят и чудо исчезновения скупых даров как пыли под дождем в наказание за скупость - художественные образы принципа справедливости.

Это поэтическая рефлексия, стилизованная в духе наставлений мудреца. Может быть в духе Корана? Да. Но не только. Это стилизация под Коран. Она в духе всех наставников мира, которые брали на себя смелость, чтобы не погибло общество, поучать богатых давать средства на содержание нищих и бедных. Отдай все нищему - и будешь богат близостью к Богу, Аллаху, Небу. Будешь завистлив и скуп - потеряешь все. Это идея народных сказок всех времен и народов. Поэзию народных сказок увидел в этих аятах Пушкин и пересказал по своему, в стихах.

\section{3. Девятое подражание. (переложение аята 261 (259) суры «Корова») ${ }^{72}$}

Аллах: «Тот, кто проходил мимо селения, а оно было разрушено до оснований,... сказал: «Как оживит это Аллах, после того, как оно умерло?». И умертвил его Аллах на сто лет, потом воскресил. Он сказал: «Сколько ты пробыл?». Тот сказал: «Пробыл я день или часть дня». Он сказал: «Нет, ты пробыл сто лет! И посмотри на твою пищу и питье, оно не испортилось. И посмотри на своего осла - для того, чтобы Нам сделать тебя знамением для людей, - посмотри на кости, как Мы их поднимаем, а потом одеваем мясом». И когда стало ему ясно, он сказал: «Я знаю, что Аллах мощен над всякой вещью!»».

Образ чуда, совершенного Аллахом, очаровал Пушкина своим сюжетом, и поэт переработал его в прелестную сказку:

\footnotetext{
${ }^{72}$ Аят 261 (259), сура 2 «Корова».// Коран. С. 57.
} 
И путник усталый на бога роптал:

Он жаждой томился и тени алкал.

В пустыне блуждая три дня и три ночи,

И зноем и пылью тягчимые очи

С тоской безнадежной водил он вокруг,

И кладезь под пальмою видит он вдруг.

И к пальме пустынной он бег устремил, И жадно холодной струей освежил

Горевшие тяжко язык и зеницы, И лег, и заснул он близ верной ослицы И многие годы над ним протекли

По воле владыки небес и земли.

Настал пробужденья для путника час; Встает он и слышит неведомый глас: «Давно ли в пустыне заснул ты глубоко?» И он отвечает: уж солнце высоко На утреннем небе сияло вчера; С утра я глубоко проспал до утра.

Но голос: «О путник, ты долее спал; Взгляни: лег ты молод, а старцем восстал; Уж пальма истлела, а кладязь холодный Иссяк и засохнул в пустыне безводной, Давно занесенный песками степей; И кости белеют ослицы твоей».

И горем объятый мгновенный старик, Рыдая, дрожащей главою поник... И чудо в пустыне тогда совершилось: Минувшее в новой красе оживилось; Вновь зыблется пальма тенистой главой; Вновь кладезь наполнен прохладой и мглой.

И ветхие кости ослицы встают,

И телом оделись, и рев издают;

И чувствует путник силу и радость;

В крови заиграла воскресшая младость;

Святые восторги наполнили грудь:

И с богом он дале пускается в путь.

Казалось бы, в «Девятом подражании» Пушкин через миф - наконец-то прав Достоевский? - передает дух Корана. Отнюдь нет. «Путник усталый» - мусульманин? Нет. Он просто путник. Разве из стихотворения видно, что это арабская пустыня, а не, например, прикаспийские степи? Пальмы растут во всех теплых странах, например, на юге Украины и на Кавказе. А ослы обитают где угодно. Нет здесь мусульманской специфики, сколько не всматривайся в идеологическое увеличительное стекло.

Пушкин восхитился динамикой чуда: путник ропщет на Бога, Бог путника усыпляет, воскрешает, превращает в старика, возвращает ему молодость и таким образом приводит к вере в Свое всесилие. Чудо с воскрешением и омоложением - древний сюжет во всех религиях. В нем тоска человека о бессмертии. Мы знаем, как Пушкин относился к рассказам о чудесах. Он их называет «ложью», «баснями», «мифами». И Коран для Пушкина - это, как мы уже знаем, собрание сказок. А со сказками у поэта особые отношения. Он влюблен в их поэзию. «Что за прелесть эти сказки! Каждая есть поэма!», - пишет Пушкин брату Льву Сергеевичу и создает поэтические переложения народных сказок: «Сказку о рыбаке и рыбке», «Сказку о мертвой царевне и о семи богатырях», «Сказку о золотом петушке», «Сказку о попе и работнике его Балде», сказочные феерии «Руслан и Людмила», «Сказка о царе Салтане, о сыне его славном и могучем богатыре князе Гвидоне Салтановиче и прекрасной царевне Лебеди».

И прелестную сказку в стихах - «Девятое подражание» Корану.

\section{4. В чем же смысл всемирности поэзии Пушкина?}

Я закончил свои интерпретации пушкинских «Подражаний Корану». А теперь давайте вспомним тезисы, через которые Достоевский оценивает эти стихи, и дадим им оценку.

1) Текст Достоевского: «Вот рядом с этим религиозным мистицизмом религиозные же строфы из Корана или «Подражания Корану»». Мой вывод: «или» Достоевского, уравнивающее религиозный документ и стихи, не корректно, в пушкинских подражаниях нет религиозных строф.

2) Достоевский: «Разве тут не мусульманин»? Мой ответ: - «Нет».

3) Достоевский: «Разве это не самый дух Корана?». - Нет.

4) Достоевский: «Разве это не... меч его (Корана - А. Д.)?». - Нет.

5) Достоевский: «Разве это... не простодушная величавость веры?». - Нет.

6) Достоевский: «Разве это не... грозная кровавая сила ее (веры - А. Д.)?». - Нет.

Но на эти вопросы можно ответить и подругому. В пушкинских стихах и мусульманин, и христианин, и буддист, в них и араб, и казах, и русский, и американец, и европеец. Сравнительный анализ текстов Корана и «Подражаний Корану» подтвердил гипотезу, с которой я приступал к изучению этого пуш- 
кинского стихотворного цикла. Нет в этих стихах ничего из того, что говорил о них Достоевский в «Пушкинской речи». Пушкин в «Подражаниях» - не исследователь культуры арабского народа и не пропагандист мусульманской общинной народно-религиозной специфики. Всемирность, всемирная отзывчивость Пушкина не в нацеленности поэта на воспевание религии и народа и не в верности народно-религиозной почве. Она в его спо- собности вырваться из сферы притяжения почвы и «служить себе» - поэту. И не важно, на какой материал Пушкин опирается, создавая стихи: на Коран, Библию, эпизоды из русской истории и культуры, русские народные сказки или западные романы - основной принцип поэта: цель поэзии - поэзия.

В этом принципе - «памятник нерукотворный» поэта. И никому не дано исказить его смысл.

\section{Список литературы:}

1. Пушкин А. С. Подражания Корану. Посвящено П. А. Осиповой.// Пушкин А. С. Полн. собр. соч. в десяти томах. М.-Л. Издательство АН СССР. Т. 2. С. 204-211. «Подражания Корану» написаны в ноябре 1824 г. Впервые опубликованы в 1826 г. В них Пушкин воспользовался переводом Корана с французского на русский М. И. Веревкина изд. 1790 г. Далее по тексту ссылки на произведения Пушкина приводятся как: Пушкин. Номер тома и номер страницы.

2. Достоевский Ф. М. «Дневник писателя» на 1880 год. Пушкин (очерк). Произнесено 8 июня в заседании Общества любителей российской словесности.// Достоевский Ф. М. Полн. собр. соч. в тридцати томах. Л., «Наука». 1980. Т. 26. С. 136-149.Далее по тексту ссылки на произведения Достоевского приводятся как: Достоевский. Номер тома и номер страницы.

3. $\quad$ Пушкин А. С. Подражания Корану. Примечания. //Пушкин. Т. 2. С. 210.

4. Достоевский Ф. М. «Дневник писателя» на 1880 год. Пушкин (очерк). Произнесено 8 июня в заседании Общества любителей российской словесности.// Достоевский Ф. М. Т. 26. С. 146.

5. Алиев Р. Послесловие. // Коран. С. 730.

6. Аят 5, сура 21 «Пророки». // Коран. Перевод и комментарии И. Ю. Крачковского. М., Главная редакция восточной литературы издательства «Наука». Язычи. 1990. С. 266. Далее ссылки на текст Корана приводятся как: Коран. Номер страницы.

7. Пушкин А. С.-Вяземскому П. А. Конец марта-начало апреля 1825 г. Из Михайловского в Москву. // Пушкин. Т. 10. С. 135.

8. Гордеев К. Пушкин А. С. Подражания Корану.// http://www.tatworld.ru/article.shtml?article $=240 \S i o n=0 \&$ heading $=0$

9. Пушкин А. С. Евгений Онегин. Ранние редакции. Глава 7. Альбом Онегина.// http://www.rvb.ru/pushkin/01text/04onegin/02edit/0853.htm

10. Достоевский Ф. М. «Дневник писателя» на 1880 год. Пушкин (очерк). Произнесено 8 июня в заседании Общества любителей российской словесности.// Достоевский. Т. 26. С. 146.

11. Соловьев В. С. Магомет: Его жизнь и религиозное учение // Библиотека «Вехи». http://islamdag.ru/vse-ob-islame/7676

12. Пушкин А. С. Талисман. // Пушкин. Т. 2. С. 35-36.

13. Пушкин А. С. О народной драме и драме «Марфа Посадница».// Пушкин. Т. 7. С. 211.

14. Аяты 1-2, сура 80 «Нахмурился». // Коран. С.489.

15. Аяты 26(25)-29(28), сура 20 «Та ха».//Коран.С. 258-259.

16. «Ислам и мусульмане в русской литературе XIX века». М., Благотворительный фонд «Путь»./http://www.islamdag.ru/vse-ob-islame/6048; см. также Фомичев С. А. «Подражания Корану». Генезис, архитектоника и композиция цикла.// http://feb-web.ru/feb/pushkin/ serial/v81/v81-022-.htm

17. Подробно см. Давыдов А. П. Неполитический либерализм в России. М. Мысль. 2012.

18. См. Давыдов А. П. Душа Гоголя. Опыт социокультурного анализа. М, Новый Хронограф. 2008.

19. Пушкин А. С. Подражания Корану.//Пушкин. Т. 2. С. 210.

20. Там же.

21. Алиев Р. Послесловие.// Коран. С. 730. 
22. Томашевский Б. В. Примечания. Подражания Корану. //Пушкин. Т 2. С. 425-426

23. Достоевский Ф. М. «Дневник писателя» на 1880 год. Пушкин (очерк). Произнесено 8 июня в заседании Общества любителей российской словесности.//Достоевский. Т. 26. С. 146.

24. Достоевский Ф. М. «Дневник писателя» на 1880 год. Пушкин (очерк). Произнесено 8 июня в заседании Общества любителей российской словесности.//Достоевский. Т. 26. С. 146-147.

25. Сура 91 «Солнце». //Коран. С. 500-501.

26. Пушкин А. С. - Жуковскому В. А. 31 октября 1824 г. Из Михайловского и Тригорского в Петербург: «Милый, прибегаю к тебе. Посуди о моем положении. Приехав сюда, был я всеми встречен как нельзя лучше, но скоро все переменилось: отец, испуганный моей ссылкою, беспрестанно твердил, что и его ожидает та же участь; Пещуров, назначенный за мною смотреть, имел бесстыдство предложить отцу моему должность распечатывать мою переписку, короче - быть моим шпионом; вспыльчивость и раздражительная чувствительность отца не позволяли мне с ним объясниться; я решился молчать. Отец начал упрекать брата в том, что я преподаю ему безбожие. Я все молчал. Получают бумагу, до меня касающуюся. Наконец, желая вывести себя из тягостного положения, прихожу котцу, прошу его позволения объясниться откровенно... Отец осердился. Я поклонился, сел верхом и уехал. Отецпризываетбратаиповелеваетемунезнаться aveccemonstre, cefils dénaturé...(Жуковский, думай о моем положении и суди.) Голова моя закипела. Иду к отцу, нахожу его с матерью и высказываю все, что имел на сердце целых три месяца. Кончаю тем, что говорю ему в последний раз. Отец мой, воспользуясь отсутствием свидетелей, выбегает и всему дому объявляет, что я его бил, хотел бить, замахнулся, мог прибить... Перед тобою не оправдываюсь. Но чего же он хочет для меня с уголовным своим обвинением? рудников сибирских и лишения чести? спаси меня хоть крепостию, хоть Соловецким монастырем. Не говорю тебе о том, что терпят за меня брат и сестра - еще раз спаси меня. 31 окт. А. П. Поспеши: обвинение отца известно всему дому. Никто не верит, но все его повторяют. Соседи знают. Я с ними не хочу объясняться - дойдет до правительства, посуди, что будет. Доказывать по суду клевету отца для меня ужасно, а на меня и суда нет. Я hors la loi. P.S. Надобно тебе знать, что я уже писал бумагу губернатору, в которой прошу его о крепости, умалчивая о причинах. П. А. Осипова, у которой пишу тебе эти строки, уговорила меня сделать тебе и эту доверенность. Признаюсь, мне немного на себя досадно, да, душа моя, - голова кругом идет». // Пушкин. Т. 10. С. 107.

27. Пушкин в примечании указывает, что «Переложение первое» написано как переложение суры «Награды».// Пушкин. Т. 2. С. 210. Таково название суры в тексте Корана, переведенного М. И. Веревкиным, которым пользовался Пушкин. В переводе В. М. Похоровой эта сура именуется «Солнце восходящее». В переводе И. Ю. Крачковского, которым я пользуюсь, она называется «Солнце».

28. Аяты 1-8, сура 91 «Солнце». //Коран. С. 500.

29. Аят 1, сура 90 «Город».// Коран. С.499.

30. Аяты 1-3(4), сура 89 «Заря».// Коран. С. 498.

31. Аяты 1-3, сура 92 «Ночь».// Коран. С. 501.

32. Аяты 35(32)-37(34), сура 74 «Завернувшийся».// Коран. С. 479.

33. Пушкин А. С. Подражания Корану. Примечания.//Пушкин. Т. 2. С. 210-211.

34. Пушкин А. С. Подражания Корану. // Пушкин. Т. 2. С. 204.

35. Лермонтов М. Ю. Демон.// Лермонтов М. Ю. Собр. соч. в 4-х т. М. Изд-во «Правда». 1949 г. T. 2. C. 435.

36. Сура 33 «Сонмы». // Коран. С.343-350.

37. Аят 30, сура 33 «Сонмы». // Коран. С.346.

38. Аят 32, сура 33 «Сонмы» // Коран. С. 346.

39. Аят 49(50), сура 33 «Сонмы» // Коран. С. 348.

40. Аят 50, сура 33 «Сонмы» // Коран. С. 348.

41. Пушкин А. С. Подражание Корану. // Пушкин. С. 204-205.

42. Пушкин А. С. Евгений Онегин. Ранние редакции. Глава третья.// http://www.rvb.ru/pushkin /01text/04onegin/02edit/0853.htm

43. Пушкин А.С. Подражания Корану. // Пушкин. Т. 2. С. 211.

44. Аят 28, сура 33 «Сонмы».// Коран. С.346. 
45. Сура 80 «Нахмурился».// Коран. С.489-490.

46. Сура 22 «Хадж».// Коран. С.274-281.

47. Комментарии. Сура 80.// Коран. С.638.

48. Фомичев С. А. «Подражания Корану». Генезис, архитектоника и композиция цикла // http://feb-web.ru/feb/pushkin/serial/v81/v81-022-.htm

49. Аяты 11-15, сура 80 «Нахмурился». // Коран. С.489.

50. Аят 2, сура 22 «Хадж». // Коран. С. 274.

51. Рылеев К.Ф.-Пушкину А.С. Конец апреля 1825 г. Петербург//Гордеев К. Пушкин. Подражания Корану.// См. http://www.tatworld.ru/article.shtml?article=240§ion=0\&heading $=0$

52. Аят 260 (258), сура 2 «Корова». // Коран. С. 56.

53. Джованни Пико делла Мирандола. Речь о достоинстве человека. Пер. с ит. Л.Брагиной.// http://www.opentextnn.ru/man/?id=1812

54. Пушкин А. С. Подражания Корану.// Пушкин. Т. 2. С. 211.

55. Сура 48 «Победа».// Коран. С. 418-421.

56. Аят 27, сура 48 «Победа».//Коран. С. 421. 1.Аль-Ма́ сджид аль-Хара́ м (араб. קارحلا دجسلالا Запретная (заповедная) мечеть) - главная мечеть, во внутреннем дворе которой находится Кааба. Расположена в Мекке в Саудовской Аравии. Разрешение войти в запретную мечетьэто награда Аллаха человеку за веру. 2.мусульманин, совершающий хадж, бреет голову. 3.«Укоротить»-значит укоротить время намаза.

57. Аят 1, сура 48 «Победа».//Коран. С. 418

58. Томашевский Б. В. Подражания Корану.// Пушкин. Т. 2. Примечания. С. 426.

59. Аят 29, сура 48 «Победа».// Коран. С. 421.

60. Аят 15, сура 48 «Победа».// Коран. С. 420.

61. Рылеев К. Ф.-Пушкину А. С. Конец апреля 1825 г. Петербург. // Гордеев К. http://www.tatworld.ru/article.shtml?article $=240 \S$ ion $=0$ \&heading $=0$

62. В других переводах Корана сура «Завернувшийся» переводится как «Робкий».

63. Аяты 1(1)-7(7), сура 74 «Завернувшийся».// Коран. С. 478.

64. Аяты 1(1)-4(4), сура 73 “Завернувшийся». // Коран. С. 477.

65. Аят 261 (259), сура 2 «Корова».// Коран. С. 57.

66. В. М. Розин Личность и трагедия Марины Цветаевой // Культура и искусство. - 2012. - 5. - С. 59 - 67.

\section{References (transliteration):}

1. Pushkin A. S. Podrazhaniya Koranu. Posvyashcheno P. A. Osipovoi.// Pushkin A. S. Poln. sobr. soch. v desyati tomakh. M.-L. Izdatel'stvo AN SSSR. T. 2. S. 204-211. «Podrazhaniya Koranu» napisany v noyabre $1824 \mathrm{~g}$. Vpervye opublikovany v $1826 \mathrm{~g}$. V nikh Pushkin vospol'zovalsya perevodom Korana s frantsuzskogo na russkii M. I. Verevkina izd. 1790 g. Dalee po tekstu ssylki na proizvedeniya Pushkina privodyatsya kak: Pushkin. Nomer toma i nomer stranitsy.

2. Dostoevskii F. M. «Dnevnik pisatelya» na 1880 god. Pushkin (ocherk). Proizneseno 8 iyunya v zasedanii Obshchestva lyubitelei rossiiskoi slovesnosti.// Dostoevskii F. M. Poln. sobr. soch. v tridtsati tomakh. L., «Nauka». 1980. T. 26. S. 136-149.Dalee po tekstu ssylki na proizvedeniya Dostoevskogo privodyatsya kak: Dostoevskii. Nomer toma i nomer stranitsy.

3. Pushkin A. S. Podrazhaniya Koranu. Primechaniya. //Pushkin. T. 2. S. 210.

4. Dostoevskii F. M. «Dnevnik pisatelya» na 1880 god. Pushkin (ocherk). Proizneseno 8 iyunya v zasedanii Obshchestva lyubitelei rossiiskoi slovesnosti.// Dostoevskii F. M. T. 26. S. 146.

5. Aliev R. Posleslovie. // Koran. S. 730.

6. Ayat 5, sura 21 «Proroki». // Koran. Perevod i kommentarii I. Yu. Krachkovskogo. M., Glavnaya redaktsiya vostochnoi literatury izdatel'stva «Nauka». Yazychi. 1990. S. 266. Dalee ssylki na tekst Korana privodyatsya kak: Koran. Nomer stranitsy.

7. Pushkin A. S.-Vyazemskomu P. A. Konets marta-nachalo aprelya 1825 g. Iz Mikhailovskogo v Moskvu. // Pushkin. T. 10. S. 135.

8. Gordeev K. Pushkin A. S. Podrazhaniya Koranu.// http://www.tatworld.ru/article.shtml?article= 240§ion $=0$ \&heading $=0$ 
9. Pushkin A. S. Evgenii Onegin. Rannie redaktsii. Glava 7. Al'bom Onegina.// http://www.rvb.ru/pu shkin/01text/04onegin/02edit/0853.htm

10. Dostoevskii F. M. «Dnevnik pisatelya» na 1880 god. Pushkin (ocherk). Proizneseno 8 iyunya v zasedanii Obshchestva lyubitelei rossiiskoi slovesnosti.// Dostoevskii. T. 26. S. 146.

11. Solov'ev V. S. Magomet: Ego zhizn’ i religioznoe uchenie // Biblioteka «Vekhi». http://islamdag.ru/ vse-ob-islame/7676

12. Pushkin A. S. Talisman. // Pushkin. T. 2. S. 35-36.

13. Pushkin A. S. O narodnoi drame i drame «Marfa Posadnitsa».// Pushkin. T. 7. C. 211.

14. Ayaty 1-2, sura 80 «Nakhmurilsya». // Koran. S.489.

15. Ayaty 26(25)-29(28), sura 20 «Ta kha».//Koran.S. 258-259.

16. Podrobno sm. Davydov A. P. Nepoliticheskii liberalizm v Rossii. M. Mysl'. 2012.

17. Sm. Davydov A. P. Dusha Gogolya. Opyt sotsiokul'turnogo analiza. M, Novyi Khronograf. 2008.

18. Pushkin A. S. Podrazhaniya Koranu.//Pushkin. T. 2. S. 210.

19. Aliev R. Posleslovie.// Koran. S. 730.

20. Tomashevskii B. V. Primechaniya. Podrazhaniya Koranu. //Pushkin. T 2. S. 425-426

21. Dostoevskii F. M. «Dnevnik pisatelya» na 1880 god. Pushkin (ocherk). Proizneseno 8 iyunya v zasedanii Obshchestva lyubitelei rossiiskoi slovesnosti.//Dostoevskii. T. 26. S. 146.

22. Dostoevskii F. M. «Dnevnik pisatelya» na 1880 god. Pushkin (ocherk). Proizneseno 8 iyunya v zasedanii Obshchestva lyubitelei rossiiskoi slovesnosti.//Dostoevskii. T. 26. S. 146-147.

23. Sura 91 «Solntse». //Koran. S. 500-501.

24. Pushkin A. S.-Zhukovskomu V. A. 31 oktyabrya 1824 g. Iz Mikhailovskogo i Trigorskogo v Peterburg: «Milyi, pribegayu k tebe. Posudi o moem polozhenii. Priekhav syuda, byl ya vsemi vstrechen kak nel'zya luchshe, no skoro vse peremenilos': otets, ispugannyi moei ssylkoyu, besprestanno tverdil, chto i ego ozhidaet ta zhe uchast'; Peshchurov, naznachennyi za mnoyu smotret', imel besstydstvo predlozhit' ottsu moemu dolzhnost' raspechatyvat' moyu perepisku, koroche - byt' moim shpionom; vspyl'chivost' i razdrazhitel'naya chuvstvitel'nost' ottsa ne pozvolyali mne s nim ob"yasnit'sya; ya reshilsya molchat'. Otets nachal uprekat' brata v tom, chto ya prepodayu emu bez bozhie. Ya vse molchal. Poluchayut bumagu, do menya kasayushchuyusya. Nakonets, zhelaya vyvesti sebya iz tyagostnogo polozheniya, prikhozhu k ottsu, proshu ego pozvoleniya ob"yasnit'sya otkrovenno... Otets oserdilsya. Ya poklonilsya, sel verkhom i uekhal. Otets prizyvaet brata i povelevaet emu ne znat'sya avec ce monstre, ce fils dénaturé... (Zhukovskii, dumai o moem polozhenii i sudi.) Golova moya zakipela. Idu k ottsu, nakhozhu ego s mater'yu i vyskazyvayu vse, chto imel na serdtse tselykh tri mesyatsa. Konchayu tem, chto govoryu emu v poslednii raz. Otets moi, vospol'zuyas' otsutstviem svidetelei, vybegaet i vsemu domu ob"yavlyaet, chto ya ego bil, khotel bit', zamakhnulsya, mog pribit'... Pered toboyu ne opravdyvayus'. No chego zhe on khochet dlya menya s ugolovnym svoim obvineniem? rudnikov sibirskikh i lisheniya chesti? spasi menya khot' krepostiyu, khot' Solovetskim monastyrem. Ne govoryu tebe o tom, chto terpyat za menya brat i sestra - eshche raz spasi menya. 31 okt. A. P. Pospeshi: obvinenie ottsa izvestno vsemu domu. Nikto ne verit, no vse ego povtoryayut. Sosedi znayut. Ya s nimi ne khochu ob"yasnyat'sya - doidet do pravitel'stva, posudi, chto budet. Dokazyvat' po sudu klevetu ottsa dlya menya uzhasno, a na menya i suda net. Ya hors la loi. R.S. Nadobno tebe znat', chto ya uzhe pisal bumagu gubernatoru, v kotoroi proshu ego o kreposti, umalchivaya o prichinakh. P. A. Osipova, u kotoroi pishu tebe eti stroki, ugovorila menya sdelat' tebe i etu doverennost'. Priznayus', mne nemnogo na sebya dosad no, da, dusha moya, - golova krugom idet». // Pushkin. T. 10. S. 107.

25. Ayaty 1-8, sura 91 «Solntse». //Koran. S. 500.

26. Ayat 1, sura 90 «Gorod».// Koran. S.499.

27. Ayaty 1-3(4), sura 89 «Zarya».// Koran. S. 498.

28. Ayaty 1-3, sura 92 «Noch»»// Koran. S. 501.

29. Ayaty 35(32)-37(34), sura 74 «Zavernuvshiisya».// Koran. S. 479.

30. Pushkin A. S. Podrazhaniya Koranu. Primechaniya.//Pushkin. T. 2. S. 210-211.

31. Pushkin A. S. Podrazhaniya Koranu. // Pushkin. T. 2. C. 204.

32. Lermontov M. Yu. Demon.// Lermontov M. Yu. Sobr. soch. v 4-kh t. M. Izd-vo «Pravda». 1949 g. T. 2. S. 435.

33. Sura 33 «Sonmy». // Koran. S.343-350.

34. Ayat 30, sura 33 «Sonmy». // Koran. S.346. 
35. Ayat 32, sura 33 «Sonmy» // Koran. S. 346.

36. Ayat 49(50), sura 33 «Sonmy»// Koran. S. 348.

37. Ayat 50, sura 33 «Sonmy» // Koran. S. 348.

38. Pushkin A. S. Podrazhanie Koranu. // Pushkin. S. 204-205.

39. Pushkin A. S. Evgenii Onegin. Rannie redaktsii. Glava tret'ya.// http://www.rvb.ru/pushkin/01text /04onegin/02edit/0853.htm

40. Pushkin A.S. Podrazhaniya Koranu. // Pushkin. T. 2. S. 211.

41. Ayat 28, sura 33 «Sonmy».// Koran. S.346.

42. Sura 80 «Nakhmurilsya».// Koran. S.489-490.

43. Sura $22 \ll$ Khadzh».// Koran. S.274-281.

44. Kommentarii. Sura 80.// Koran. S.638.

45. Fomichev S. A. «Podrazhaniya Koranu». Genezis, arkhitektonika i kompozitsiya tsikla // http://feb-web.ru/feb/pushkin/serial/v81/v81-022-.htm

46. Ayaty 11-15, sura 80 «Nakhmurilsya». // Koran. S.489.

47. Ayat 2, sura 22 «hhadzh». // Koran. S. 274.

48. Ryleev K.F.-Pushkinu A.S. Konets aprelya 1825 g. Peterburg//Gordeev K. Pushkin. Podrazhaniya Koranu.// Sm. http://www.tatworld.ru/article.shtml?article $=240 \S i o n=0 \&$ heading $=0$

49. Ayat 260 (258), sura 2 «Korova». // Koran. S. 56.

50. Dzhovanni Piko della Mirandola. Rech' o dostoinstve cheloveka. Per. s it. L.Braginoi.// http://www.opentextnn.ru/man/?id=1812

51. Pushkin A. S. Podrazhaniya Koranu.// Pushkin. T. 2. C. 211.

52. Sura 48 «Pobeda».// Koran. C. 418-421.

53. Ayat 27, sura 48 «Pobeda».//Koran. S. 421. 1.Al'-Másdzhid al'-Kharám (arab. קارحلا دجسملا Zapretnaya (zapovednaya) mechet') - glavnaya mechet', vo vnutrennem dvore kotoroi nakhoditsya Kaaba. Raspolozhena v Mekke v Saudovskoi Aravii. Razreshenie voiti v zapretnuyu mechet'-eto nagrada Allakha cheloveku za veru. 2.musul'manin, sovershayushchii khadzh, breet golovu. 3.«Ukorotit’»znachit ukorotit' vremya namaza.

54. Ayat 1, sura 48 «Pobeda».//Koran. S. 418

55. Tomashevskii B. V. Podrazhaniya Koranu.// Pushkin. T. 2. Primechaniya. S. 426.

56. Ayat 29, sura 48 «Pobeda».// Koran. S. 421.

57. Ayat 15, sura 48 «Pobeda».// Koran. S. 420.

58. Ryleev K. F.-Pushkinu A. S. Konets aprelya 1825 g. Peterburg. // Gordeev K. http://www.tatworld.ru /article.shtml?article $=240$ §ion $=0$ \&heading $=0$

59. Ayaty 1(1)-7(7), sura 74 «Zavernuvshiisya».// Koran. S. 478.

60. Ayaty 1(1)-4(4), sura 73 "Zavernuvshiisya». // Koran. S. 477.

61. Ayat 261 (259), sura 2 «Korova».// Koran. S. 57.

62. V. M. Rozin Lichnost' i tragediya Mariny Tsvetaevoi // Kul'tura i iskusstvo. - 2012. - 5. - C. 59 - 67. 